\begin{tabular}{|c|l|}
\hline Title & $\begin{array}{l}\text { Dicarboxylic acids and water-soluble organic carbon in aerosols in New Delhi, India, in winter : Characteristics and } \\
\text { formation processes }\end{array}$ \\
\hline Author(s) & Miyazaki, Y uzo; Aggarwal, Shankar G.; Singh, Khem; Gupta, Prabhat K.; Kawamura, Kimitaka \\
\hline Citation & $\begin{array}{l}\text { Journal of Geophysical Research : A tmospheres, 114, D19206 } \\
\text { https://doi.org/10.1029/2009JD011790 }\end{array}$ \\
\hline Issue Date & 2009-10-08 \\
\hline Doc URL & http://hdl.handle.net/2115/39604 \\
\hline Rights & An edited version of this paper was published by A GU. Copyright 2009 A merican Geophysical Union. \\
\hline Type & article (author version) \\
\hline File Information & JGRA 114_D19206.pdf \\
\hline
\end{tabular}

Instructions for use 


\section{Dicarboxylic acids and water-soluble organic carbon in aerosols in New Delhi, India in winter: Characteristics and formation processes}

Yuzo Miyazaki, ${ }^{1}$ Shankar G. Aggarwal, ${ }^{1}$ Khem Singh, ${ }^{2}$ Prabhat K. Gupta, ${ }^{2}$ and Kimitaka Kawamura ${ }^{1}$

${ }^{1}$ Institute of Low Temperature Science, Hokkaido University, Sapporo, Japan

${ }^{2}$ National Physical Laboratory, New Delhi, India

Short title: DIACIDS AND WSOC IN NEW DELHI 


\section{Abstract.}

Day- and night-time aerosol samples were collected at an urban site in New Delhi, India, in winter 2006-2007. They were studied for low molecular weight dicarboxylic acids and related compounds as well as total water-soluble organic carbon (TWSOC). High concentrations of diacids (up to $6.03 \mu \mathrm{g} \mathrm{m}^{-3}$ ), TWSOC, and OC were obtained, which are substantially higher than those previously observed at other urban sites in Asia. Daytime TWSOC/OC ratio (37\%) was on average higher than that in nighttime (25\%). In particular, more water-soluble OC (M-WSOC) to TWSOC ratio in daytime (50\%) was twice higher than in nighttime (27\%), suggesting that aerosols in New Delhi are photochemically more processed in daytime to result in more water-soluble organic compounds. Oxalic acid $\left(\mathrm{C}_{2}\right)$ was found as the most abundant dicarboxylic acid, followed by succinic $\left(\mathrm{C}_{4}\right)$ and malonic $\left(\mathrm{C}_{3}\right)$ acids. Contributions of $\mathrm{C}_{2}$ to M-WSOC were greater (av. 8\%) in nighttime than daytime (av. 3\%). Positive correlations of $\mathrm{C}_{2}$ with malic acid $\left(\mathrm{hC}_{4}\right)$, glyoxylic acid $\left(\omega \mathrm{C}_{2}\right)$, and relative humidity suggest that secondary production of $\mathrm{C}_{2}$ probably in aqueous phase is important in nighttime via the oxidation of both longer-chain diacids and $\omega \mathrm{C}_{2} \cdot \mathrm{C}_{2}$ also showed a positive correlation with potassium $\left(\mathrm{K}^{+}\right)$in nighttime, suggesting that the enhanced $\mathrm{C}_{2}$ concentrations are associated with biomass/biofuel burning. More tight, positive correlation between less water-soluble OC (L-WSOC) and $\mathrm{K}^{+}$was found in both day- and night-time, suggesting that L-WSOC, characterized by longer chain and/or higher molecular weight compounds, is significantly influenced by primary emissions from biomass/biofuel burning. 


\section{Introduction}

Water-soluble organic carbon (WSOC) can significantly alter the hygroscopicity of aerosols and is important in determining the cloud condensation nuclei (CCN) activity of particles [Novakov and Penner, 1993; Saxena et al., 1995; Facchini et al., 1999]. WSOC is also considered to be associated with a major fraction of secondary organic aerosols (SOA), which is formed by oxidation of volatile organic compounds (VOCs) followed by condensation on existing particles and/or nucleation. Oxalic acid $\left(\mathrm{C}_{2}\right)$, generally the most abundant dicarboxylic acid in the atmosphere [Kawamura and Sakaguchi, 1999], is formed from oxidation of VOCs and aqueous phase chemistry in cloud/fog droplets, as well as from primary emissions from fossil fuel combustion, and biomass burning [Norton et al., 1983; Kawamura and Kaplan, 1987; Kawamura et al., 1996; Narukawa et al., 1999; Warneck, 2003; Kawamura and Yasui, 2005; Sorooshian et al., 2006].

Warneck [2003] suggested that oxalic acid is produced from glyoxal in cloud droplets in the marine atmosphere, and glyoxal is formed by oxidation of acetylene and glycolaldehyde formed by oxidation of ethene. It is noted that in these processes glyoxylic acid is a key intermediate, whereas diacids, except for oxalic acid, are not produced. Ervens et al. [2004] also consider the production of glyoxal from toluene and of glycolaldehyde from isoprene as well as aqueous phase reactions of adipic and glutaric acids produced by the oxidation of cyclohexene. Recent studies further suggest the formation of oxalic acid by the oxidation of methylglyoxal, an oxidation product of toluene and isoprene, via intermediates such as pyruvic and acetic acids [Lim et al., 2005; Carlton et al., 2006]. Altieri et al. [2006] suggested that this reaction pathway also forms oligomers. The knowledge of the sources of diacids and WSOC is important to understand the formation processes of SOA that act as $\mathrm{CCN}$. This information should provide important implications for regional air quality and global climate. 
High loadings of carbonaceous aerosols in northern India have been reported in recent years [Prasad et al., 2006; Rengarajan et al., 2007]. In fact, the largest OC emission per unit surface area in the world occurs over India [Ramanathan et al., 2007]. The northern part of India has a population of more than 210 millions and thus has large anthropogenic emission sources. Venkataraman et al. [2005] calculated that residential biofuel combustion is the most important source of carbonaceous aerosols in India, pointing out its potential impact on climate change in the South Asian region. Carbonaceous aerosols emitted from the region can be transported downwind to Indian Ocean [e.g., Neusüß et al., 2002; Ramanathan et al., 2002; Stone et al., 2007] and Himalayan regions [Prasad et al., 2006; Srivastava et al., 2006]. Field observations of the Indian Ocean Experiment (INDOEX) have indicated that visible amounts of carbonaceous aerosols are present annually over the northern Indian Ocean, beginning in November and lasting until April [e.g., Neusüß et al., 2002; Ramanathan et al., 2002]. The meteorology during the period is characterized by low-level northeasterly winds with little precipitation, thus atmospheric particles are scarcely scavenged in this region [Jayaraman et al., 1998].

A few previous studies on aerosol organic compounds in India have been made primarily at several urban sites [e.g., Sharma et al., 2003; Chowdhury et al., 2007]. These studies identified solvent-extractable organic compounds, including $n$-alkanes and polycyclic aromatic hydrocarbons (PAH), mainly from the viewpoint of source identification. City of New Delhi, the capital of India, is located within the Delhi metropolitan region. In spite of their importance in regional air quality and climate, organic aerosols including dicarboxylic acids and WSOC have not been characterized in New Delhi.

In this study, we conducted the first measurements of dicarboxylic acids and WSOC in the aerosols collected at an urban site of New Delhi, India, from September 2006 to April 2007. 
Here, we present the temporal variability of the concentrations and the mass fractions of dicarboxylic acids in WSOC, and discuss the factors that control the molecular distributions of dicarboxylic acids and levels of WSOC in the Indian urban atmosphere.

\section{Experiments}

\subsection{Aerosol Sampling}

The sampling location in New Delhi $\left(28.37^{\circ} \mathrm{N}, 77.13^{\circ} \mathrm{E}\right)$, India, is shown in Figure 1. The figure also shows the annual emission rates of anthropogenic OC and VOC over India estimated for the year 2006 [Zhang et al., 2009], which are given at http://www.cgrer.uiowa. edu/EMISSION_DATA_new/data/intex-b_emissions/. They include emissions from power plants, industry, residential biofuel/fossil fuel, and transportation. Anthropogenic OC and VOC are strongly emitted from the northwest to southeast of India $\left(22^{\circ}-34^{\circ} \mathrm{N}, 70^{\circ}-90^{\circ} \mathrm{E}\right)$.

Total suspended particulate (TSP) samples were collected on a rooftop (15 m above the ground) of a building on a campus of National Physical Laboratory (NPL) in New Delhi from September 2006 to April 2007. The samplings were conducted using pre-combusted (at $450^{\circ} \mathrm{C}$ for at least $6 \mathrm{~h})$ quartz fiber filters $(25 \times 20 \mathrm{~cm})$ and a high-volume air sampler at a flow rate of $1200 \mathrm{~L} \mathrm{~min}^{-1}$. The total volume of the samples ranged between 800 and $990 \mathrm{~m}^{3}$. The average face velocity of the TSP samplings was $42 \mathrm{~cm} \mathrm{~s}^{-1}$, which is close to the dry-deposition velocity of particles with a diameter of $\sim 100 \mu \mathrm{m}$ roughly calculated for the sampling conditions [Jacobson, 2005]. This suggests that the effect of dry deposition on the measured aerosol concentrations is insignificant for particles with diameters smaller than $\sim 100 \mu \mathrm{m}$.

The sampling site is located at a residential area of New Delhi, which has less undue influence of local emissions from nearby traffic or industries [Chowdhury et al., 2007]. Although most of the samples were collected in wintertime (November 2006-February 2007), 
three samples obtained in late summer (September) and one sample in late spring (April) were also studied here. The sampling time for each sample was approximately $12 \mathrm{hrs}$, starting at 06:00 LT and 18:00 LT, which are referred to as daytime and nighttime samples, respectively. During the course of the sampling, the local wind speed typically ranged between 2-8 $\mathrm{m} \mathrm{s}^{-1}$. The wind direction generally remained northwesterly to southwesterly with no systematic differences in daytime and nighttime. Analytical results of sixteen samples are shown in this paper.

\subsection{Dicarboxylic Acids and Related Water-Soluble Compounds}

The filter samples were analyzed for dicarboxylic acids (DCAs) by the method of Kawamura and Ikushima [1993] and Kawamura [1993]. A part of the quartz-fiber filter was cut in pieces and soaked in $5 \mathrm{ml}$ milli-Q water, and then water-soluble species were extracted with pure water $(5 \mathrm{ml} \times 3$ times $)$ under ultrasonication. The extracts were combined in a $50 \mathrm{ml}$ flask after filtration with quartz wool, and concentrated to almost dryness, to which $14 \%$ $\mathrm{BF}_{3} / n$-butanol was added. The extracts and reagents were then heated for $1 \mathrm{~h}$ to convert the carboxyl groups to butyl esters and aldehyde groups to dibutoxy acetals. The derived butyl esters and acetals were extracted with $n$-hexane. They were concentrated and dissolved in $50 \mu \mathrm{l}$ of $n$-hexane. The butyl esters and acetals were determined by a capillary gas chromatograph (Hewlett-Packard GC6890N) with a flame ionization detector. Each compound was identified based on retention times of GC peaks with those of authentic standards and mass spectra obtained by GC/mass spectrometry.

Recoveries of authentic standards spiked on a precombusted quartz-fiber filter were $73 \%$ and $81 \%$ for oxalic and malonic acids, respectively, and greater than $95 \%$ for succinic and adipic acids. This recovery was taken into account to calculate the concentrations of the DCAs 
in the filter samples. The variations due to analytical errors were tested by analyzing different sections of the same filter sample repeatedly, and the coefficient of deviation was found to be less than $8 \%$ for major diacids. The levels of field blanks were generally less than $17 \%$ of mass concentrations for the major species. Concentrations of diacids and related compounds presented here were corrected for the field blanks.

\subsection{Total and Fractionated WSOC and Inorganic Species}

In a broad definition, WSOC can be divided into two fractions, more and less soluble in water. To isolate the WSOC components into more and less water-soluble fractions, we used a macroporous nonionic resin (DAX-8) with TOC detection [Duarte and Duarte, 2005; Sullivan and Weber, 2006; Miyazaki et al., 2009]. A number of previous studies have used the XAD-8 resin to isolate less water-soluble organic fractions of organic compounds, mainly humic substances, from natural water samples. However, because the XAD-8 resin is no longer available commercially, the comparability of a substitute resin, DAX-8, was utilized in the present study. The technical specifications (e.g., pore size and surface area) and adsorption characteristics of these two resins are almost the same [e.g., Peuravuori et al., 2001]. The mechanism for the adsorption of organic solutes onto the resin is related to the molecular size of the solute in a water sample and to the certain interactions between more or less water-soluble organic compounds and nonionic adsorbing resin under pre-adjusted $\mathrm{pH}$ conditions.

In the present WSOC analysis, the volume of DAX-8 resin packed in the column was $5 \mathrm{ml}$. A filter cut of $1.54 \mathrm{~cm}^{2}$ was extracted with ultra pure Milli-Q water using an ultrasonic bath (10 $\min \times 3$ times). The total extracts $(100 \mathrm{ml})$ were then filtrated with a disc filter (Millex-GV, $0.22 \mu \mathrm{m}$, Millipore). Total WSOC (TWSOC) in the extracts was then determined by a total 
organic carbon (TOC) analyzer (Sievers, 810) [Miyazaki et al., 2006].

Another aliquot of water extracts was adjusted to $\mathrm{pH}=2$ using hydrochloric acid $(\mathrm{HCl})$ before being pumped onto the DAX-8 resin. The DAX resin then retains hydrophobic compounds in the sample solution. In this study, we define more water-soluble OC (M-WSOC) as such that pass through the DAX-8 column, whereas less water-soluble OC (L-WSOC) as those retained on the DAX-8 resin. L-WSOC is calculated as TWSOC - M-WSOC. The variations due to analytical errors were tested by analyzing different sections of the same filter sample three times. The resulting coefficients of deviation were less than $4 \%$ and $7 \%$ for TWSOC and M-WSOC, respectively. The levels of field blanks were less than 5\% (TWSOC) and $13 \%(\mathrm{M}-\mathrm{WSOC})$ of the ambient aerosol concentrations.

The fractions of M-WSOC and L-WSOC are operational, but they are related to the carbon chain length and number of functional groups per molecule. Briefly, M-WSOC is composed of highly oxygenated and/or lower molecular weight organic compounds. These compounds are more hydrophilic. L-WSOC is comprised of organic compounds that contain longer carbon chain and higher molecular weight structures. To characterize the DAX-8 resin under the current experimental conditions, authentic organic compounds relevant to atmospheric aerosol components were tested in the laboratory. This laboratory experiments were made in order to determine whether each standard pass through the column. Briefly, authentic water-soluble organic species were dissolved in purified water and adjusted to $\mathrm{pH}=2$ using $\mathrm{HCl}$. They were then pumped onto the column, followed by detection by the TOC analyzer.

Passing tests of selected organic compounds are summarized in Table 1. The results showed that aliphatic dicarboxylic acids and carbonyls ( $<4$ carbons), saccharides, and amines were classified as M-WSOC, whereas aliphatic dicarboxylic acids and carbonyls (>3-4 
carbons), aromatic acids, phenols, organic nitrates, cyclic acids, and fulvic acids were classified as L-WSOC. We confirmed that M-WSOC is associated with highly water soluble and/or low molecular weight organics, while L-WSOC is with less water-soluble and/or higher molecular weight organics. Our results are basically same as those by XAD-8 resin [Sullivan and Weber, 2006]. For $\mathrm{C}_{4}$ dicarboxylic acids, maleic and fumaric acids are cis-trans isomers, having identical molecular weights. However, the water solubility of maleic acid is about two orders of magnitude higher than that of fumaric acid (Table 1). This difference with respect to chemical properties can explain the result that fumaric acid was retained on the DAX resin whereas maleic acid passed through the resin. On the basis of the water solubility of the compounds listed in Table 1, separation between M-WSOC and L-WSOC occurs in the water solubility between 3-8 g per $100 \mathrm{~g}$ for the compounds studied here. It should be noted that aromatic compounds are included in L-WSOC, even if their molecular weights are low (e.g., catechol) and water solubility is relatively high.

Another aliquot of filtrated water extracts from the samples was used to determine major anions and cations with Metrohm ion chromatographs (Model 761 compact IC, Metrohm, Herisau, Switzerland). Anions were measured using a SI-90 4E (SHODEX) column equipped with a suppressor with eluent of $1.8 \mathrm{mM} \mathrm{Na}_{2} \mathrm{CO}_{3}+1.7 \mathrm{mM} \mathrm{NaHCO}_{3}$. For cation analysis, we used a YK-421 (SHODEX) column with $4 \mathrm{mM} \mathrm{H}_{3} \mathrm{PO}_{4}$ as eluent.

\subsection{OC and EC}

Mass concentrations of OC and EC were measured using a Sunset lab EC/OC analyzer (Sunset Laboratory, Inc., Tigard, OR, USA). In the present study, we used a temperature protocol based on that proposed by the National Institute for Occupational Safety and Health (NIOSH) [Birch and Cary, 1996; Miyazaki et al., 2007]. 
Possible interferences were assessed by the measurement of field blanks. The OC and EC values for a filter punch of field blanks were 1.6 and $0.0 \mu \mathrm{gC} \mathrm{m} \mathrm{m}^{-3}$, respectively, in correspondence with a sample volume of $936 \mathrm{~m}^{3}$ of air. The equivalent concentration of OC accounted for $2 \%$ of the average OC concentrations of the real samples. Data of OC presented here are all corrected against the field blanks. The variations due to analytical errors were tested by analyzing different sections of the same filter sample three times, and the coefficient of deviation was less than $6 \%$ for OC and 3\% for EC. Using the measured mass concentrations of OC and TWSOC, water-insoluble OC (WIOC) is defined as WIOC $=$ OC - TWSOC.

\section{Results and Discussion}

\subsection{Mass Concentrations and Molecular Distributions of Dicarboxylic Acids}

Figure 2 presents temporal variations in the mass concentrations of water-soluble organic components as well as some meteorological parameters from September 2006 to April 2007. In general, temporal trends of TWSOC and total dicarboxylic acids (TDCA) were similar (Figure $2 \mathrm{a}-\mathrm{b})$, with $\mathrm{r}^{2}=0.51$. Average concentrations of OC, WIOC, M-WSOC, and L-WSOC were $68.4 \pm 37.9,47.9 \pm 31.8,7.8 \pm 3.7$, and $12.3 \pm 4.6 \mu \mathrm{gC} \mathrm{m}{ }^{-3}$, respectively. TWSOC accounted for $31 \pm 11 \%$ of OC, where M-WSOC accounted for $36 \pm 12 \%$ of TWSOC during the study period. The TWSOC/OC ratios are within a range (20-40\%) reported for other urban sites in Asia in winter [Yang et al., 2005; Miyazaki et al., 2006; Ho et al., 2007]. Concentrations of TDCA ranged between $0.84-6.03 \mu \mathrm{g} \mathrm{m}^{-3}$, with an average of $2.33 \pm 1.31 \mu \mathrm{g} \mathrm{m}^{-3}$. This value is $2-5$ times larger than those reported in Chinese cities [Wang et al., 2006; Ho et al., 2007] and urban Tokyo [Kawamura and Ikushima, 1993]. Because these samples were all obtained at urban sites in the same season (winter), the difference in the concentrations can be attributed to the largest OC emission per unit surface area being found in India [Ramanathan et al., 2007]. 
Average molecular distributions of dicarboxylic acids, ketoacids, and $\alpha$-dicarbonyls for

194

195

196 day- and night-time are shown in Figure 3. Their values are also summarized in Table 2. Oxalic acid $\left(\mathrm{C}_{2}\right)$ was detected as the most abundant diacid species $\left(1.43 \pm 0.99 \mu \mathrm{g} \mathrm{m}^{-3}\right)$, followed by succinic $\left(C_{4}\right)\left(0.30 \pm 0.16 \mu \mathrm{g} \mathrm{m}^{-3}\right)$ and malonic acids $\left(C_{3}\right)\left(0.19 \pm 0.05 \mu \mathrm{g} \mathrm{m}{ }^{-3}\right)$. On average, concentrations of $\mathrm{C}_{2}-\mathrm{C}_{4}$ diacids accounted for $82 \%$ of TDCA. The average concentration of $\mathrm{C}_{2}$ is substantially larger than that observed at other urban sites in Asia, such as Tokyo (0.27-1.35 $\left.\mu \mathrm{g} \mathrm{m}^{-3}\right)$ [Kawamura and Ikushima, 1993; Sempere and Kawamura, 1994], Beijing (0.22 $\mu \mathrm{g}$ $\mathrm{m}^{-3}$ ) [Huang et al., 2005], and Hong Kong (0.35-0.37 $\left.\mu \mathrm{g} \mathrm{m}^{-3}\right)$ [Yao et al., 2004]. Differences between day- and night-time molecular distributions are discussed in section 3.4.

Concentrations of total ketoacids ranged from 0.03 to $0.64 \mu \mathrm{g} \mathrm{m}{ }^{-3}$, with an average of $0.16 \pm 0.09 \mu \mathrm{g} \mathrm{m}^{-3}$ (Table 2). Glyoxylic acid $\left(\omega \mathrm{C}_{2}\right)$ (average: $0.12 \pm 0.08 \mu \mathrm{g} \mathrm{m}^{-3}$ ) was found as a dominant ketoacid, followed by 4-oxobutanoic acid $\left(\omega \mathrm{C}_{4}\right)$ and pyruvic acid $(\mathrm{Pyr}) . \omega \mathrm{C}_{2}$ is an intermediate in the $\mathrm{OH}$ oxidation of glyoxal, glycolate, methylglyoxal, and acetic acid [Kawamura et al., 1996; Ervens et al., 2004], which results in oxalic acid [Lim et al., 2005; Carlton et al., 2006]. The predominance of $\omega_{2}$ was also observed at the Chinese urban sites [Ho et al., 2007]. The average concentration of $\omega_{2}$ in the New Delhi samples was approximately three times greater than that observed in Chinese urban aerosols, whereas the average ratio of $\omega \mathrm{C}_{2}$ to total diacids in New Delhi (0.040) was similar to that observed at the Chinese urban sites (0.042). Concentrations of $\alpha$-dicarbonyls ranged from 0.01 to $0.25 \mu \mathrm{g} \mathrm{m}^{-3}$ with an average of $0.05 \pm 0.05 \mu \mathrm{g} \mathrm{m} \mathrm{m}^{-3}$. These values are substantially higher than those at Chinese urban sites in the winter of 2003 (av. $0.02 \mu \mathrm{g} \mathrm{m}^{-3}$ ).

For inorganic species, average mass concentrations of sulfate $\left(\mathrm{SO}_{4}{ }^{2-}\right)$ and nitrate $\left(\mathrm{NO}_{3}{ }^{-}\right)$in winter were $13.6 \pm 6.1 \mu \mathrm{g} \mathrm{m}^{-3}$ and $18.9 \pm 4.7 \mu \mathrm{g} \mathrm{m}^{-3}$, respectively (Figure $2 \mathrm{c}$ ). These values are similar to those $\left(12.7 \pm 6.2 \mu \mathrm{g} \mathrm{m}^{-3}\right.$ for $\mathrm{SO}_{4}{ }^{2-}$ and $13.3 \pm 6.6 \mu \mathrm{g} \mathrm{m}^{-3}$ for $\left.\mathrm{NO}_{3}{ }^{-}\right)$in winter observed at 
Hisar $\left(29.3^{\circ} \mathrm{N}, 75.7^{\circ} \mathrm{E}\right)$, an urban site $\sim 150 \mathrm{~km}$ northwest of New Delhi [Rengarajan et al., 2007]. This similarity of the concentrations suggests that the observed levels of aerosol concentrations might be representative on a regional scale during the study period without any significant influence from local sources.

\subsection{Mass Fractions of WSOC and Dicarboxylic Acids}

Figure 4 presents temporal variations in the mass fractions of the M-WSOC, L-WSOC, and WIOC relative to OC. Daytime TWSOC/OC ratio was on average $37 \pm 9 \%$, which is higher than the nighttime ratio of $25 \pm 9 \%$. The average M-WSOC/TWSOC ratio was substantially greater in daytime $(50 \pm 6 \%)$ than in nighttime $(27 \pm 8 \%)$. TWSOC concentrations were similar in daytime (av. $10.4 \mu \mathrm{gC} \mathrm{m} \mathrm{m}^{-3}$ ) and nighttime (av. $9.6 \mu \mathrm{gC} \mathrm{m} \mathrm{m}^{-3}$ ) (Table 2). In contrast, concentration of M-WSOC was higher in daytime $\left(9.4 \mu \mathrm{gC} \mathrm{m} \mathrm{m}^{-3}\right)$ than in nighttime $(6.1 \mu \mathrm{gC}$ $\mathrm{m}^{-3}$ ), leading to the higher mass fractions of M-WSOC in TWSOC in daytime. The higher contribution of more water-soluble organic compounds in the daytime samples can be explained by an enhanced photochemical production of polar compounds in daytime.

Kawamura and Ikushima [1993] suggested that the $\mathrm{C}_{3} / \mathrm{C}_{4}$ ratio can be used as an indicator of enhanced photochemical production of diacids, because $\mathrm{C}_{3}$ is produced by photochemical oxidation of $\mathrm{C}_{4}$ in the atmosphere. In the present study, $\mathrm{C}_{3} / \mathrm{C}_{4}$ ratios ranged between 0.40 and 1.06 with an average of 0.62 , which are similar to those $(0.59-0.63)$ reported for aerosols in China in winter [Ho et al., 2007] and those (0.5-0.9) for winter aerosols in Tokyo [Kawamura and Ikushima, 1993]. The average $\mathrm{C}_{3} / \mathrm{C}_{4}$ ratio was higher in daytime (0.66) than in nighttime (0.58), being consistent with an enhanced photochemical processing as indicated by the higher TWSOC/OC and M-WSOC/TWSOC ratios in daytime.

Figure 5 shows time series of mass fractions of $\mathrm{C}_{2}-\mathrm{C}_{4}$ in $\mathrm{M}-\mathrm{WSOC}$ and relative 
abundances of $\mathrm{C}_{2}-\mathrm{C}_{9}$ as well as $\mathrm{C}_{2}$ relative to TDCA in day- and night-time. In contrast to the diurnal difference in the M-WSOC/TWSOC ratios, the average mass fractions of $\mathrm{C}_{2}$ in M-WSOC exhibited larger contributions (av. 8\%) in nighttime than in daytime (av. 3\%). Much higher contributions of $\mathrm{C}_{2}-\mathrm{C}_{4}$ to M-WSOC were found in nighttime largely due to the enhanced concentrations of $\mathrm{C}_{2}$ and decreased M-WSOC concentrations in nighttime. In fact, oxalic acid $\left(\mathrm{C}_{2}\right)$ was found to account for $70 \pm 7 \%$ of total $\mathrm{C}_{2}-\mathrm{C}_{9}$ diacids in nighttime, which is greater than that in daytime $(59 \pm 9 \%)$. It is interesting to note that the average $\mathrm{C}_{2}$ concentration in nighttime $\left(1.91 \mu \mathrm{g} \mathrm{m}^{-3}\right)$ is almost twice higher than in daytime $\left(0.96 \mu \mathrm{g} \mathrm{m}^{-3}\right)$ (Figure 3). Increased relative abundance of $\mathrm{C}_{2}$ in nighttime suggests a possible formation of $\mathrm{C}_{2}$ in nighttime, a point to be discussed in section 3.4.

Figure 6 shows relations between total $\mathrm{C}_{2}-\mathrm{C}_{4}$ concentrations and M-WSOC contents in day- and night-time. A linear relation was found between $\mathrm{C}_{2}-\mathrm{C}_{4}$ diacid concentrations and M-WSOC both in daytime $\left(r^{2}=0.94\right)$ and nighttime $\left(r^{2}=0.81\right)$. This suggests that sources for $\mathrm{C}_{2}-\mathrm{C}_{4}$ and M-WSOC (and their precursors) were similar. However, M-WSOC concentrations are significantly higher (1.5 times) in daytime than in nighttime, whereas daytime concentrations of $\mathrm{C}_{2}-\mathrm{C}_{4}$ diacids are lower by $\sim 60 \%$ than in nighttime (see Figure 6 ). These results suggest that more water-soluble organic compounds, except for $\mathrm{C}_{2}-\mathrm{C}_{4}$ diacids, contribute more significantly to M-WSOC in daytime, and are likely produced by photochemical processes. Photochemical production of $\mathrm{C}_{2}-\mathrm{C}_{4}$ diacids can also occur in daytime, as indicated by the higher $\mathrm{C}_{3} / \mathrm{C}_{4}$ ratio in daytime.

Azelaic acid $\left(\mathrm{C}_{9}\right)$ has been proposed as oxidation product of unsaturated fatty acids. Unsaturated fatty acids are abundant in terrestrial plant leaves and contain a double bond predominantly at C-9 position [Kawamura and Gagosian, 1987; Kawamura and Kaplan, 1987]. In fact, $C_{9}$ was generally found as the fourth most abundant diacid species in both day- 
and night-time samples, with average concentrations of $0.070 \mu \mathrm{g} \mathrm{m} \mathrm{m}^{-3}$ and $0.072 \mu \mathrm{g} \mathrm{m} \mathrm{m}^{-3}$, respectively. These $\mathrm{C}_{9}$ concentrations account for $4 \%$ and $3 \%$ of $\mathrm{C}_{2}-\mathrm{C}_{9}$ diacids in day- and night-time, respectively. Although it is difficult to quantitatively determine the contribution of biogenic emissions to the observed aerosols from our data alone, the result suggests that biogenic emissions of unsaturated fatty acids contribute to the New Delhi aerosols to some extent.

\subsection{Contribution of Biomass/Biofuel Burning Emissions}

It has been well recognized that the emissions from biomass/biofuel burning include a large portion of water soluble organic species [e.g., Mayol-Bracero et al., 2002]. With regard to the molecular distributions of diacids shown in Figure 3, a similar distribution of diacids dominated by $\mathrm{C}_{2}$, followed by $\mathrm{C}_{4}$, was also reported for biomass burning plumes [e.g., Narukawa et al., 1999; Legrand et al., 2007]. Chowdhury et al. [2007] inferred that 20\% of $\mathrm{PM}_{2.5}$ aerosol sampled in Delhi in winter was attributable to primary emissions from biomass burning using various molecular markers (e.g., levoglucosan). To investigate the effects of biomass/biofuel burning on the sources of observed organic compounds, water soluble potassium $\left(\mathrm{K}^{+}\right)$is used as a tracer of wood burning [e.g., Andreae, 1983]. Scatter plots of $\mathrm{C}_{2}$, M-WSOC, and L-WSOC with $\mathrm{K}^{+}$are shown in Figure 7. $\mathrm{C}_{2}$ and M-WSOC showed moderate positive correlations with $\mathrm{K}^{+}$in nighttime $\left(\mathrm{r}^{2}=0.34-0.43\right)$, suggesting that emissions from biomass/biofuel burning are apparently an important source for $\mathrm{C}_{2}$ and $\mathrm{M}-\mathrm{WSOC}$ in nighttime at the sampling site. More pronounced linear relation was observed between L-WSOC and $\mathrm{K}^{+}$ in both daytime $\left(r^{2}=0.70\right)$ and nighttime $\left(r^{2}=0.75\right)$. These tight, positive correlations suggest that majority of L-WSOC originated from biomass/biofuel combustion.

Gao et al. [2003] used the data set of $\mathrm{C}_{2}-\mathrm{C}_{5}$ diacids in wood burning on savanna fires, 
showing an increase in the $\mathrm{C}_{2}$ to $\mathrm{K}^{+}$ratio, ranging from 0.02 over the fire to 0.25 after 40 min of aging. This $\mathrm{C}_{2}$ formation during the initial aging of aerosols was attributed to fast secondary production in the smoke plumes [Gao et al., 2003]. Even higher enrichment of $\mathrm{C}_{2}$ with respect to $\mathrm{K}^{+}$was observed for the nighttime samples of the present study with an average $\mathrm{C}_{2} / \mathrm{K}^{+}$ratio of $0.61 \pm 0.35$, indicating a fast secondary production of $\mathrm{C}_{2}$ in the burning plume. On the other hand, an average $\mathrm{C}_{2} / \mathrm{K}^{+}$ratio in daytime was $0.30 \pm 0.15$, indicating less significant production of $\mathrm{C}_{2}$ in the burning plume compared to that in nighttime (a point to be discussed in the following section).

Contribution of wood burning to secondary formation of diacids is also supported by a positive correlation between $\mathrm{C}_{9}$ and $\mathrm{K}^{+}$in the nighttime samples $\left(\mathrm{r}^{2}=0.28\right)$. Unsaturated fatty acids such as oleic acid mainly emitted by wood burning and meat cooking [Rogge et al., 1991] can be the source of diacids. Oleic acid, once emitted, is rapidly oxidized to result in $\mathrm{C}_{9}$ and other products, which can be further decomposed to $\mathrm{C}_{5}$ and $\mathrm{C}_{4}$. The moderate correlation between $\mathrm{C}_{9}$ and $\mathrm{K}^{+}$in the nighttime samples suggests a certain contribution of wood burning to $\mathrm{C}_{9}$.

\subsection{Potential Processes for the Net Production of Oxalic Acid}

As shown in section 3.2, relative increases in the concentrations and fractions of $\mathrm{C}_{2}$ were observed for the nighttime samples. One might argue that descending of boundary layer (BL) height in nighttime could accumulate air pollutants within the BL, leading to the enhancement of the mass concentrations of $\mathrm{C}_{2}$ and other species in the atmosphere near the ground surface in nighttime. However, the difference in the $\mathrm{C}_{2}$ mass fractions between day- and night-time cannot be explained by the changes in the BL heights. Although time-resolved measurements of $\mathrm{C}_{2}$ precursors (i.e., VOCs) are not available, no significant difference was found between the 
day- and night-time concentrations of primary emission tracers such as $\mathrm{EC}$ and $\mathrm{K}^{+}$. In fact, the average concentrations of EC $\left(40.4 \mu \mathrm{gC} \mathrm{m}^{-3}\right)$ and $\mathrm{K}^{+}\left(3.55 \mu \mathrm{g} \mathrm{m}{ }^{-3}\right)$ in daytime were similar to those in nighttime (EC: $36.6 \mu \mathrm{gC} \mathrm{m} \mathrm{m}^{-3}, \mathrm{~K}^{+}: 3.65 \mu \mathrm{g} \mathrm{m}^{-3}$ ). This suggests that the difference in the $\mathrm{C}_{2}$ mass fractions has been unlikely due to differences in the amount of precursor emissions in day- and night-time. Rather, the relative increases in the concentrations and fractions of $\mathrm{C}_{2}$ in nighttime can be explained by the differences in net production processes of $\mathrm{C}_{2}$ between day and night: (1) more significant production of $C_{2}$ and/or (2) less significant loss of $C_{2}$ in nighttime than in daytime.

Previous studies have reported that low molecular weight dicarboxylic acids were sometimes found in the coarse mode, such as sea salt, dust, and soil particles [Neusüss et al., 2000; Mochida et al., 2003; Huang et al., 2006]. $\mathrm{C}_{2}$ and other acidic species in the gas phase could be adsorbed onto alkaline coarse particles [e.g., Neusüss et al., 2000]. In this study, however, concentration of sodium $\left(\mathrm{Na}^{+}\right)$was considerably low with no significant difference between day and night. Moreover, a correlation between $\mathrm{C}_{2}$ and $\mathrm{Na}^{+}$was poor $\left(\mathrm{r}^{2}<0.09\right)$ for both day- and night-time samples, suggesting that the production of $\mathrm{C}_{2}$ associated with sea salt particles is unlikely in the New Delhi samples studied. Similarly, $\mathrm{C}_{2}$ also showed poor correlation with calcium $\left(\mathrm{Ca}^{2+}\right)\left(\mathrm{r}^{2}<0.09\right)$, indicating an insignificant contribution of dust particles to $\mathrm{C}_{2}$ production.

One possible explanation for the increases in the relative concentrations and fractions of $\mathrm{C}_{2}$ in nighttime is a secondary formation of $\mathrm{C}_{2}$ in aqueous phase of aerosols. In aqueous phase, $\mathrm{C}_{2}$ is known to be formed by $\mathrm{OH}$ oxidation of various precursors including longer-chain dicarboxylic acids and glyoxylic acid $\left(\omega \mathrm{C}_{2}\right)$. Kawamura and Ikushima [1993] proposed that malic acid $\left(\mathrm{hC}_{4}\right)$, hydroxylated dicarboxylic acid, can be formed by hydration of maleic acid and/or hydroxylation of succinic acid, and is further oxidized to produce $\mathrm{C}_{2}$. Evidence for 
hydroxylation is based on detection of $\mathrm{C}_{5}$ and $\mathrm{C}_{6}$ hydoxyacids [Appel et al., 1979]. Since no direct emissions have been identified for $\mathrm{hC}_{4}$, the change in the relative abundances of $\mathrm{C}_{4}$ and $\mathrm{hC}_{4}$ may indicate a progress of photochemical aging of aerosols probably in aqueous phase.

Figure 8 shows concentrations of $\mathrm{C}_{2}$ and its contribution to total diacids $\left(\mathrm{C}_{2} / \mathrm{TDCA}\right)$ as a function of $\mathrm{hC}_{4} /\left(\mathrm{hC}_{4}+\mathrm{C}_{4}\right)$ in day- and night-time. Although $\mathrm{hC}_{4}$ showed lower concentrations than $\mathrm{C}_{4}$, their relative abundance fluctuated significantly. The $\mathrm{C}_{2}$ concentrations and $\mathrm{hC}_{4} /\left(\mathrm{hC}_{4}+\mathrm{C}_{4}\right)$ ratios showed a strong correlation $\left(\mathrm{r}^{2}=0.86\right)$ for the nighttime samples. Similarly, the $\mathrm{C}_{2}$ /TDCA ratios also showed an increase with increasing ratios of $\mathrm{hC}_{4} /\left(\mathrm{hC}_{4}+\mathrm{C}_{4}\right)$, with a moderate correlation $\left(r^{2}=0.21\right)$ in nighttime. Furthermore, $C_{2}$ was well correlated with $C_{3}\left(r^{2}=0.66\right), C_{4}\left(r^{2}=0.82\right)$, and glutaric acid $\left(C_{5} ; r^{2}=0.80\right)$. These results provide further evidence for aqueous phase secondary production of $\mathrm{C}_{2}$ in aerosols via decays of longer-chain dicarboxylic acids, rather than primary emission. However, such a correlation between $\mathrm{C}_{2}$ and $\mathrm{hC}_{4} /\left(\mathrm{hC}_{4}+\mathrm{C}_{4}\right)$ was not found for the daytime samples. This may suggest that heterogeneous reactions to produce $\mathrm{C}_{2}$ in aerosol phase are not important in daytime because relative humidity was low (av. $\sim 55 \%$, see Figure 2d), possibly leading to lower water contents of aerosols in daytime. On the other hand, higher relative humidity (av. $\sim 70 \%$ ) in nighttime is favorable for aqueous phase chemistry in ambient aerosols. In fact, time-resolved meteorological data showed that the maximum relative humidity reached nearly $100 \%$ during most of the nighttime samplings (Figure 2d), supporting an occurrence of fogs or clouds near the ground surface. On the other hand, the relative humidity in daytime never reached $100 \%$. Moreover, a positive correlation between $\mathrm{C}_{2} /$ TDCA and the average relative humidity $\left(\mathrm{r}^{2}=0.49\right)$ was found for all the data sets, which also suggests aqueous phase production of $\mathrm{C}_{2}$ in aerosols.

The above results support the possibility of aqueous phase productions of $\mathrm{C}_{2}$ via decays of longer-chain dicarboxylic acids, but do not exclude an importance of other pathways such as 
production of $\mathrm{C}_{2}$ via the oxidation of $\omega_{2}$. Sorooshian et al. [2007] conducted aircraft measurements and found that relative abundance of $\omega \mathrm{C}_{2}$ in total organic acids detected is higher in cloud droplets than in the aerosol samples collected below clouds. Their result suggests the formation of $\omega C_{2}$ in an early stage of liquid phase reaction. In the present study, average concentrations of $\omega \mathrm{C}_{2}$ were as high as 0.11 and $0.13 \mu \mathrm{g} \mathrm{m}^{-3}$ in day- and night-time, respectively, which correspond to $7-12 \%$ of the $\mathrm{C}_{2}$ mass concentrations. Concentrations of $\mathrm{C}_{2}$ and $\omega \mathrm{C}_{2}$ highly correlate $\left(\mathrm{r}^{2}=0.65\right)$ in nighttime, whereas the correlation is low $\left(\mathrm{r}^{2}=0.35\right)$ in daytime (data not shown as a figure). Pyr has also been reported to act as a precursor of $\mathrm{C}_{2}$ via $\omega \mathrm{C}_{2}$ in aqueous phase [Lim et al., 2005; Carlton et al., 2006] and shown to originate from aromatic hydrocarbons and isoprene [Talbot et al., 1995]. In fact, Pyr and $\omega C_{2}$ were positively correlated $\left(r^{2}=0.53\right)$ in our nighttime samples. These results further support the secondary production of $\mathrm{C}_{2}$ in nighttime. It is noted that a $\omega \mathrm{C}_{2} / \mathrm{C}_{2}$ ratio in nighttime (av. 0.067) is lower than that in daytime (av. 0.119), possibly due to the production of $\mathrm{C}_{2}$ from $\omega \mathrm{C}_{2}$ in nighttime. This process may proceed within a time scale of the aerosol sampling $(\sim 12 \mathrm{~h})$, leading to the lower $\omega \mathrm{C}_{2} / \mathrm{C}_{2}$ ratio in nighttime.

It has been shown that $\omega \mathrm{C}_{2}$ produces $\mathrm{C}_{2}$ more efficiently at higher $\mathrm{pH}$, because the rate constant of the oxidation of anion (glyoxylate) is an order of magnitude greater than that of $\omega \mathrm{C}_{2}$ [Ervens et al., 2003a]. In the present study, however, no significant difference in the imbalance between anions and cations was seen for the day- and night-time samples (data not shown). The ammonium $\left(\mathrm{NH}_{4}{ }^{+}\right)$-to- $\mathrm{SO}_{4}{ }^{2-}$ molar ratios were 4.3 and 4.9 in day- and night-time, respectively. Although these ratios indicate that there was sufficient $\mathrm{NH}_{4}{ }^{+}$to neutralize $\mathrm{SO}_{4}{ }^{2-}$, there was no significant difference in the $\mathrm{NH}_{4}{ }^{+} / \mathrm{SO}_{4}{ }^{2-}$ molar ratios between day- and night-time. These results suggest insignificant effects of $\mathrm{pH}$ on the enhanced $\mathrm{C}_{2}$ levels in nighttime. Hence, secondary production of $\mathrm{C}_{2}$ likely takes place in aqueous phase, in which oxidation of both 
longer-chain diacids and $\omega \mathrm{C}_{2}$ are important sources of $\mathrm{C}_{2}$ in the nighttime atmosphere in New Delhi.

A correlation between $\mathrm{C}_{2}$ and sulfate and its linear regression slope have been used to investigate production processes of $\mathrm{C}_{2}$ mainly via aqueous phase reactions [e.g., Yu et al, 2005], because secondary production pathways of sulfate are well established. Figure 9 shows a scatter plot between $\mathrm{C}_{2}$ and sulfate in daytime and nighttime. The $\mathrm{C}_{2}$ and sulfate concentrations showed a strong correlation for the daytime $\left(r^{2}=0.67\right)$ and nighttime samples $\left(r^{2}=0.65\right)$. Previous studies have noted similarity in size distributions of these two species, suggesting a common source [Yao et al., 2003 Crahan et al., 2004; Huang et al., 2006]. Although the size distributions of $\mathrm{C}_{2}$ and sulfate are not available and the sample number is limited in the present study, a linear regression slope of the $\mathrm{C}_{2}$ to sulfate ratio in the nighttime samples $(0.198)$ is about $60 \%$ higher than in the daytime samples $(0.125)$. The difference in the slopes together with higher concentrations of $\mathrm{C}_{2}$ in nighttime suggests more efficient production of $\mathrm{C}_{2}$ in nighttime, which can be a consequence of multistep aqueous-phase production of $\mathrm{C}_{2}$ : several subsequent oxidation steps are necessary to form $\mathrm{C}_{2}$ from VOC precursors, whereas fewer steps are required for production of sulfate [Warneck, 2003; Ervens et al., 2004; Yu et al., 2005]. The $x$-intercept of the linear relationship between $\mathrm{C}_{2}$ and $\mathrm{SO}_{4}{ }^{2-}$ found in day- and night-time suggests that an additional source of $\mathrm{SO}_{4}{ }^{2-}$ exists in addition to the different formation and loss processes of both species. One possible explanation for the intercept is that New Delhi and surrounding regions have more power plants and coal combustion [Prasad et al., 2006; Zhang et al., 2009], which produce much greater emissions of $\mathrm{SO}_{2}$ but emit fewer VOCs.

In addition to the production processes, various loss processes of $\mathrm{C}_{2}$ could affect the concentrations and fractions of $\mathrm{C}_{2} . \mathrm{C}_{2}$ is lost by its oxidation to result in $\mathrm{CO}_{2}$ [e.g., Warneck, 2003]. Zuo and Holgné [1992] suggested that photolysis of iron(III)/iron(II)-oxalato 
complexes can be an important sink of $\mathrm{C}_{2}$ in the aqueous phase in the atmosphere. Ervens et al. [2003b] used a photochemical box model and showed that photolysis of the iron-dioxalato-complex is much more effective than oxidation of $\mathrm{C}_{2}$ by $\mathrm{OH}$. On the other hand, evaporation of $\mathrm{C}_{2}$ is negligible because the vapor pressure of $\mathrm{C}_{2}$ is sufficiently low $\left(<10^{-4} \mathrm{~mm}\right.$ $\mathrm{Hg}$ ) [Saxena and Hildemann, 1996]. It is possible that rates of production and loss of $\mathrm{C}_{2}$ are different for daytime and nighttime. During nighttime, oxidation of organics may be less efficient due to the absence of sunlight and lack of $\mathrm{H}_{2} \mathrm{O}_{2}$ and $\mathrm{OH}$ production, and $\mathrm{NO}_{3}$ may act as a major oxidant. In summary, the relative increases in the concentrations and fractions of $\mathrm{C}_{2}$ in nighttime are probably due to more significant production of $\mathrm{C}_{2}$ and/or less significant loss of $\mathrm{C}_{2}$ than in daytime.

\section{Conclusions}

Measurements of water-soluble dicarboxylic acids and bulk water soluble organic carbon (WSOC) were made for the first time in ambient aerosol samples collected at an urban site in New Delhi, India, in winter 2006-2007. A macroporous nonionic (DAX-8) resin was used to quantify more- and less-WSOC, which are defined as the fractions of WSOC that passed through and retained on the DAX-8 column, respectively. On average, total WSOC (TWSOC)/OC ratio was found to be significantly higher in daytime (37\%) than in nighttime (25\%). In particular, more water-soluble OC (M-WSOC) accounted for 50\% of TWSOC in daytime, which is substantially higher than that (27\%) in nighttime. These differences can be interpreted by more pronounced photochemical production of polar organic compounds in daytime even in winter.

Average concentrations of oxalic acid $\left(\mathrm{C}_{2}\right)\left(1.43 \mu \mathrm{g} \mathrm{m}^{-3}\right)$ and total diacids $\left(2.33 \mu \mathrm{g} \mathrm{m}^{-3}\right)$ were substantially high compared to those previously reported at other urban sites in Asia. $\mathrm{C}_{2}$ 
433 was the most abundant dicarboxylic acid, followed by succinic $\left(\mathrm{C}_{4}\right)$ and malonic $\left(\mathrm{C}_{3}\right)$ acid. We

434 found that the average mass fractions of $\mathrm{C}_{2}$ in nighttime were greater $(8 \%$ of M-WSOC and $43566 \%$ of total diacids) than daytime ( $3 \%$ of M-WSOC and $54 \%$ of total diacids). Positive 436 correlations of $\mathrm{C}_{2}$ with malic acid $\left(\mathrm{hC}_{4}\right)$, glyoxylic acid $\left(\omega \mathrm{C}_{2}\right)$, and relative humidity suggest 437 that secondary production of $\mathrm{C}_{2}$ occurs possibly in aqueous aerosol phase via the oxidation of 438 longer-chain diacids and $\omega \mathrm{C}_{2}$ in the New Delhi atmosphere during nighttime. $\mathrm{C}_{2}$ also showed a 439 positive correlation with potassium in nighttime, suggesting that the enhanced net production 440 of $\mathrm{C}_{2}$ is associated with fast secondary reactions in biomass/biofuel burning plumes.

441 Less water soluble OC (L-WSOC), composed of longer carbon chain and higher 442 molecular weight organic compounds, was highly correlated with potassium in both day- and 443 night-time samples, demonstrating that majority of L-WSOC was affected by primary 444 emissions from biomass/biofuel burning. 
Acknowledgments. This research was supported by the Japanese Ministry of Education, Culture, Sports, Science and Technology (MEXT) through grant-in-aid No. 19204055 and 19710004. The study is a part of collaborative research project, Molecular Characterization and Hygroscopicity of Indian Aerosols (MOCHIA). S. G. A. acknowledges the support from the Japan Society for the Promotion of Science. 


\section{References}

Altieri, K. E., A. G. Carlton, H.-J. Lim, B. J. Turpin, and S. P. Seitzinger (2006), Evidence for oligomer formation in clouds: reactions of isoprene oxidation products, Environ. Sci. Technol, 40. 4956-4960.

Andreae, M. O. (1983), Soot carbon and excess fine potassium: Long-range transport of combustion-derived aerosols, Science, 220, 1148-1151.

Appel, B. R., E. M. Hoffer, E. L. Kothny, S. M. Wall, M. Haik, and R. L. Knights (1979), Analysis of carbonaceous material in Southern-California atmospheric aerosols. 2., Environ. Sci. Technol., 13, 98-104.

Birch, M. E., and R. A. Cary (1996), Elemental carbon-based method for monitoring occupational exposures to particulate diesel exhaust, Aerosol Sci. Technol., 25, 221- 241.

Carlton, A. G., B. J. Turpin, H. J. Lim, K. E. Altieri, and S. Seitzinger (2006), Link between isoprene and secondary organic aerosol (SOA): Pyruvic acid oxidation yields low volatility organic acids in clouds, Geophys. Res. Lett., 33, L06822, doi:10.1029/2005GL025374.

Chowdhury, Z., M. Zheng, J. J. Schauer, R. J. Sheesley, L. G. Salmon, G. R. Cass, and A. G. Russell (2007), Speciation of ambient fine organic carbon particles and source apportionment of PM2.5 in Indian cities, J. Geophys. Res., 112, D15303, doi:10.1029/2007JD008386.

Crahan, K. K., D. Hegg, D. S. Covert, and H. Jonsson (2004), An exploration of aqueous oxalic acid production in the coastal marine atmosphere, Atmos. Environ., 38, 3757-3764.

Duarte, R. M. B., and Duarte, A. C. (2005), Application of non-ionic solid sorbents (XAD Resins) for the isolation and fractionation of water-soluble organic compounds from atmospheric aerosols, J. Atmos. Chem., 51, 79-93.

Ervens, B., S. Gligorovski, and H.Herrmann (2003a), Temperature-dependent rate constants for hydroxyl radical reactions with organic compounds in aqueous phase, Phys. Chem. Chem. Phys., 5, 1811-1824.

Ervens, B., et al. (2003b), CAPRAM 2.4 (MODAC mechanism): An extended and condensed tropospheric aqueous phase mechanism and its application, J. Geophys. Res., 108(D14), 4426, doi:10.1029/2002JD002202.

Ervens, B., G. Feingold, G. J. Frost, and S. M. Kreidenweis (2004), A modeling study of aqueous production of dicarboxylic acids: 1. Chemical pathways and speciated organic mass production, J. Geophys. Res., 109, D15205, doi:10.1029/2003JD004387.

Facchini, M. C., M. Mircea, S. Fuzzi, and R. J. Charlson (1999), Cloud albedo enhancement by surface-active organic solutes in growing droplets, Nature, 401, 257- 259.

Gao, S., D. A. Hegg, P. V. Hobbs, T. W. Kirchstetter, B. I. Magi, and M. Sadilek (2003), Water-soluble organic components in aerosols associated with savanna fires in southern 
Africa: Identification, evolution, and distribution, J. Geophys. Res., 108(D13), 8491, doi:10.1029/2002JD002324.

Ho, K. F., J. J. Cao, S. C. Lee, K. Kawamura, R.-J. Zhang, J.-C. Chow, and J.-G. Watson (2007), Dicarboxylic acids, ketocarboxylic acids and dicarbonyls in urban atmosphere of China, $J$. Geophys. Res., 112, D22S27, doi:10.1029/2006JD008011.

Huang, X. F., M. Hu, L. Y. He, and X. Y. Tang (2005), Chemical characterization of water-soluble organic acids in PM2.5 in Beijing, China, Atmos. Environ., 39, 2819-2827.

Huang, X.-F., J. Z. Yu, L.-Y. He, and Z. Yuan (2006), Water-soluble organic carbon and oxalate in aerosols at a coastal urban site in China: Size distribution characteristics, sources, and formation mechanisms, J. Geophys. Res., 111, D22212, doi:10.1029/2006JD007408.

Jacobson, M. Z. (2005), Fundamentals of Atmospheric Modeling, Second Edition, Cambridge University Press, New York, pp. 813.

Jayaraman, A., D. Lubin, S. Ramachandran, V. Ramanathan, E. Woodbridge, W. D. Collins, and K. S. Zalpuri (1998), Direct observations of aerosol radiative forcing over the tropical Indian Ocean during the January-February 1996 pre-INDOEX cruise, J. Geophys. Res., 103(D12), 13,827-13,836.

Kawamura, K., and R. B. Gagosian (1987), Implications of $\omega$-oxocarboxylic acids in the remote marine atmosphere for photo-oxidation of unsaturated fatty acids, Nature, 325, 330 332.

Kawamura, K., and I. R. Kaplan (1987), Motor-exhaust emissions as a primary source for dicarboxylic acids in Los Angeles, Environ. Sci. and Technol. 21, 105-110.

Kawamura, K. (1993), Identification of $\mathrm{C}_{2}-\mathrm{C}_{10}$ (-oxocarboxylic acids, pyruvic acid, and $\mathrm{C}_{2}-\mathrm{C}_{3}$ a-dicarbonyls in wet precipitation and aerosol samples by capillary GC and GC/MS, Anal. Chem., 65, 3505-3511.

Kawamura, K., and K. Ikushima (1993), Seasonal changes in the distribution of dicarboxylic acids in the urban atmosphere. Environ. Sci. Technol. 27, 2227-2235.

Kawamura, K., H. Kasukabe, and L. A. Barrie (1996), Source and reaction pathways of dicarboxylic acids, ketoacids and dicarbonyls in Arctic aerosols: One year of observations, Atmos. Environ., 30, 1709-1722.

Kawamura, K., and F. Sakaguchi (1999), Molecular distributions of water-soluble dicarboxylic acids in marine aerosols over the Pacific Ocean including tropics, J. Geophys. Res., 104(D3), 3501-3509.

Kawamura, K., and O. Yasui (2005), Diurnal changes in the distribution of dicarboxylic acids, ketocarboxylic acids and dicarbonyls in the urban atmosphere, Atmos. Environ, 39, 1945-1960.

Legrand, M., S. Preunkert, T. Oliveira, C. A. Pio, S. Hammer, A. Gelencse'r, A. Kasper-Giebl, 
and P. Laj (2007), Origin of $\mathrm{C}_{2}-\mathrm{C}_{5}$ dicarboxylic acids in the European atmosphere inferred from year-round aerosol study conducted at a west-east transect, J. Geophys. Res., 112, D23S07, doi:10.1029/2006JD008019.

Lim, H. J., A. G. Carlton, and B. J. Turpin (2005), Isoprene forms secondary organic aerosol through cloud processing: Model simulations, Environ. Sci. Technol., 39, 4441-4446.

Mayol-Bracero, O. L., et al. (2002), Water-soluble organic compounds in biomass burning aerosols over Amazonia 2. Apportionment of the chemical composition and importance of the polyacidic fraction, J. Geophys. Res., 107(D20), 8091, doi:10.1029/2001JD000522.

Miyazaki, Y., Y. Kondo, N. Takegawa, Y. Komazaki, K. Kawamura, M. Mochida, K. Okuzawa, and R. J. Weber (2006), Time-resolved measurements of water-soluble organic carbon in Tokyo, J. Geophys. Res., 111, D23206, doi:10.1029/2006JD007125.

Miyazaki, Y., Y. Kondo, S. Han, M. Koike, D. Kodama, Y. Komazaki, H. Tanimoto, and H. Matsueda (2007), Chemical characteristics of water-soluble organic carbon in the Asian outflow, J. Geophys. Res., 112, D13209, doi:10.1029/2006JD007896.

Miyazaki, Y., et al. (2009), Chemical characterization of water-soluble organic carbon aerosols at a rural site in the Pearl River Delta, China, in the summer of 2006, J. Geophys. Res., doi:10.1029/2009JD011736, 114, D14208, doi:10.1029/2009JD011736.

Mochida, M., N. Umemoto, K. Kawamura, and M. Uematsu, Bimodal size distribution of $\mathrm{C}_{2}-\mathrm{C}_{4}$ dicarboxylic acids in the marine aerosols (2003), Geophys. Res. Lett., 30(13), 1672, doi:10.1029/2003GL017451.

Narukawa, K. Kawamura, N. Takeuchi and T. Nakajima (1999), Distribution of dicarboxylic acids and carbon isotopic compositions in aerosols from 1997 Indonesian forest fires. Geophys. Res. Lett. 26, 3101-3104.

Neusüss, C., M. Pelzing, A. Plewka, and H. Herrmann (2000), A new analytical approach for size-resolved speciation of organic compounds in atmospheric aerosol particles: Method and first results, J. Geophys. Res., 105, 4512-4527.

Neusüß, C., T. Gnauk, A. Plewka, H. Herrmann, and P. K. Quinn (2002), Carbonaceous aerosol over the Indian Ocean: OC/EC fractions and selected specifications from size-segregated onboard samples, J. Geophys. Res., 107(D19), 8031, doi:10.1029/2001JD000327.

Norton, R. B., J. M. Roberts, and B. J. Huebert, Tropospheric oxalate, Geophys. Res. Lett., 10, 517-520, 1983.

Novakov, T., and J. E. Penner (1993), Large contribution of organic aerosols to cloud-condensation-nuclei concentrations, Nature, 365, 823-826.

Peuravuori, J., P. Ingman, K. Pihlaja, and R. Koivikko (2001), Comparisons of aquatic humic matter by DAX -8 and XAD-8 resins from solid-state 13C NMR spectroscopy's point of view, Talanta, 55, 733-742. 
Prasad, A. K., R. P. Singh, and M. Kafatos (2006), Influence of coal based thermal power plants on aerosol optical properties in the Indo-Gangetic basin, Geophys. Res. Lett., 33, L05805, doi:10.1029/2005GL023801.

Ramanathan, V., et al. (2002), The Indian Ocean Experiment and the Asian brown cloud, Curr. Sci., 83(8), 947-955.

Ramanathan, V., et al. (2007), Atmospheric brown clouds: Hemispherical and regional variations in long-range transport, absorption, and radiative forcing, J. Geophys. Res., 112, D22S21, doi:10.1029/2006JD008124.

Rengarajan, R., M. M. Sarin, and A. K. Sudheer (2007), Carbonaceous and inorganic species in atmospheric aerosols during wintertime over urban and high-altitude sites in North India, $J$. Geophys. Res., 112, D21307, doi:10.1029/2006JD008150.

Rogge, W. F., L. M. Hildemann, M. A. Mazurek, G. R. Cass, and B. R. T. Simoneit (1991), Sources of fine organic aerosol, 1, Charbroilers and meat cooking operations, Environ. Sci. Technol., 25, 1112-1125.

Saxena, P., L. M. Hildemann, P. H. McMurry, and J. H. Seinfeld (1995), Organics alter hygroscopic behavior of atmospheric particles, J. Geophys. Res., 100, 18,755-18,770.

Saxena, P., and L. M. Hildemann (1996), Water-soluble organics in atmospheric particles: A critical review of the literature and application of thermodynamics to identify candidate compounds, J. Atmos. Chem., 24, 57-109.

Sempere, R., and K. Kawamura (1994), Comparative distributions of dicarboxylic-acids and related polar compounds in snow rain and aerosols from urban atmosphere, Atmos. Environ., $28,449-459$.

Sharma, D. N., A. A. Sawant, R. Uma, and D. R. Cocker III (2003), Preliminary chemical characterization of particle-phase organic compounds in New Delhi, India, Atmos. Environ., $37,4317-4323$.

Sorooshian, A., et al. (2006), Oxalic acid in clear and cloudy atmospheres: Analysis of data from International Consortium for Atmospheric Research on Transport and Transformation 2004, J. Geophys. Res., 111, D23S45, doi:10.1029/2005JD006880.

Sorooshian, A., N. L. Ng, A. W. H. Chan, G. Feingold, R. C. Flagan, and J. H. Seinfeld (2007), Particulate organic acids and overall water-soluble aerosol composition measurements from the 2006 Gulf of Mexico Atmospheric Composition and Climate Study (GoMACCS), J. Geophys. Res., 112, D13201, doi:10.1029/2007JD008537.

Srivastava, M. K., S. Singh, A. Saha, U. C. Dumka, P. Hegde, R. Singh, and P. Pant (2006), Direct solar ultraviolet irradiance over Nainital, India, in the central Himalayas for clear-sky day conditions during December 2004, J. Geophys. Res., 111, D08201, doi:10.1029/2005JD006141. 
Stone, E. A., G. C. Lough, J. J. Schauer, P. S. Praveen, C. E. Corrigan, and V. Ramanathan (2007), Understanding the origin of black carbon in the atmospheric brown cloud over the Indian Ocean, J. Geophys. Res., 112, D22S23, doi:10.1029/2006JD008118.

Sullivan, A. P., and R. J. Weber (2006), Chemical characterization of the ambient organic aerosol soluble in water: 1. Isolation of hydrophobic and hydrophilic fractions with a XAD-8 resin, J. Geophys. Res., 111, D05314, doi:10.1029/2005JD006485.

Talbot, R. W., B. W. Mosher, B. G. Heikes, D. J. Jacob, J. W. Munger, B. C. Daube, W. C. Keene, J. R. Maben, and R. S. Artz (1995), Carboxylic-acids in the rural continental atmosphere over the eastern United States during the Shenandoah Cloud and Photochemistry Experiment, J. Geophys. Res., 100, 9335-9343.

Venkataraman, C., G. Habib, A. Eiguren-Fernandez, A. H. Miguel, and S. K. Friedlander (2005), Residential biofuels in South Asia: Carbonaceous aerosol emissions and climate impacts, Science, 307, 1454-1456.

Wang, G., K. Kawamura, T. Watanabe, S. Lee, K. Ho, and J. Cao (2006), High loadings and source strengths of organic aerosols in China, Geophys. Res. Lett., 33, L22801, doi:10.1029/2006GL027624.

Warneck, P. (2003), In-cloud chemistry opens pathway to the formation of oxalic acid in the marine atmosphere, Atmos. Environ., 37, 2423-2427.

Yang, H., J. Z. Yu, S. S. H. Ho, J. Xu, W.-S. Wu, C. H. Wan, X. Wang, X. Wang, and L. Wang (2005), The chemical composition of inorganic and carbonaceous materials in PM2.5 in Nanjing, China, Atmos. Environ., 39, 3735-3749.

Yao, X. H., A. P. S. Lau, M. Fang, C. K. Chan, and M. Hu (2003), Size distributions and formation of ionic species in atmospheric particulate pollutants in Beijing, China: 2-dicarboxylic acids, Atmos. Environ., 37, 3001-3007.

Yao, X. H., M. Fang, C. K. Chan, K. F. Ho, and S. C. Lee (2004), Characterization of dicarboxylic acids in PM2.5 in Hong Kong, Atmos. Environ., 38, 963-970.

Yu, J. Z., S. F. Huang, J. H. Xu, and M. Hu (2005), When aerosol sulfate goes up, so does oxalate: Implication for the formation mechanisms of oxalate, Environ. Sci. Technol., 39, $128-133$.

Zhang, Q., D. G. Streets, G. R. Carmichael, K. He, H. Huo, A. Kannari, Z. Klimont, I. Park, S. Reddy, D. Chen, L. Duan, Y. Lei, L. Wang, and Z. Yao (2009), Asian emissions in 2006 for the NASA INTEX-B mission, Atmos. Chem. Phys. Discuss., 9, 4081-4139.

Zuo, Y., and J. Holgné (1992), Formation of hydrogen peroxide and depletion of oxalic acid in atmospheric water by photolysis of iron (III)-oxalato complexes, Environ. Sci. Technol., 26, 1014-1022. 
S. G. Aggarwal, K. Kawamura, Y. Miyazaki, Institute of Low Temperature Science, Hokkaido University, N19, W8, Kita-ku, Sapporo, 060-0819 Japan. (yuzom@lowtem.hokudai.ac.jp)

Prabhat K. Gupta, Khem Singh, Chemical Metrology Section, National Physical Laboratory, Dr. K. S. Krishnan Marg, New Delhi, 110012, India. 


\section{Figure Captions}

Figure 1. A map of India with the location of New Delhi indicated by asterisk. Anthropogenic emission estimates of OC and VOC are also shown for year 2006 over India [Zhang et al., 2009], the data of which are available at the website http://www.cgrer.uiowa.edu/ EMISSION_DATA_new/data/intex-b_emissions/.

Figure 2. Time series of speciated and identified organic aerosols, major inorganic aerosols collected in New Delhi from September 2006 to April 2007 together with meteorological data: (a) M-WSOC, L-WSOC, and WIOC, (b) total diacids, oxalic acid $\left(\mathrm{C}_{2}\right)$, malonic acid $\left(\mathrm{C}_{3}\right)$, and succinic acid $\left(\mathrm{C}_{4}\right)$, (c) sulfate and nitrate, $(\mathrm{d})$ the maximum and average relative humidity (RH), and ambient temperature. "D" indicates data corrected in daytime, whereas " $\mathrm{N}$ " indicates that in nighttime.

Figure 3. Average molecular distributions of dicarboxylic acids, ketoacids, and $\alpha$-dicarbonyls in daytime and nighttime. To highlight the concentrations of less abundant species, molecular distributions except $\mathrm{C}_{2}-\mathrm{C}_{4}$ are also shown with an enhanced $\mathrm{y}$-axis scale.

Figure 4. Mass fractions of M-WSOC, L-WSOC, and WIOC in OC during daytime and nighttime.

Figure 5. Mass fractions of $\mathrm{C}_{2}-\mathrm{C}_{4}$ in $\mathrm{M}-\mathrm{WSOC}, \mathrm{C}_{2}$ in total diacids, and relative abundances of $\mathrm{C}_{2}-\mathrm{C}_{9}$ in day- and night-time. To highlight the abundance of organic compounds shown, the $y$-axis begins at $40 \%$ in the bottom panels as $\mathrm{C}_{2}$ contributes $>40 \%$ in each category.

Figure 6. Relation between total $\mathrm{C}_{2}-\mathrm{C}_{4}$ and M-WSOC concentrations during daytime (open circle) and nighttime (solid circle).

Figure 7. Scatter plots of (a) $\mathrm{C}_{2}$, (b) M-WSOC and (c) L-WSOC with $\mathrm{K}^{+}$in daytime (open circle) and nighttime (solid circle). The correlation coefficient is based on a regression line 
that is not forced through 0 .

Figure 8. Variations of (a) $\mathrm{C}_{2}$ concentrations and (b) $\mathrm{C}_{2} / \mathrm{TDCA}$ ratios as a function of $\mathrm{hC}_{4} /\left(\mathrm{hC}_{4}+\mathrm{C}_{4}\right)$ in daytime (open circle) and nighttime (solid circle).

Figure 9. Relation between $\mathrm{C}_{2}$ and sulfate concentrations during daytime (open circle) and nighttime (solid circle). "S" indicates a slope of a linear regression. 
Table 1. Summary of the laboratory experiments for the DAX-8 resin using organic species standards. The classification as M-WSOC or L-WSOC for each compound is indicated by circles, based on their passing efficiency through the DAX-8 resin. For definition of M-WSOC and L-WSOC, see text.

\begin{tabular}{|c|c|c|c|c|c|c|c|}
\hline \multirow{2}{*}{$\begin{array}{l}\text { Functional } \\
\text { group }\end{array}$} & \multirow[b]{2}{*}{ Compounds } & \multirow{2}{*}{$\begin{array}{l}\mathrm{MW},{ }^{\mathrm{a}} \\
\mathrm{g} \mathrm{mol}^{-1}\end{array}$} & \multirow{2}{*}{$\begin{array}{c}\text { Solubility } \\
\text { in water } \\
\text { (g solute per } \\
100 \mathrm{~g} \text { water) }\end{array}$} & \multirow{2}{*}{$\begin{array}{c}\text { Concentrations, } \\
\qquad \mu g \mathrm{~L}^{-1}\end{array}$} & \multirow{2}{*}{$\begin{array}{c}\text { Passing } \\
\text { Efficiency, } \\
\%\end{array}$} & \multicolumn{2}{|c|}{ Definition in this study } \\
\hline & & & & & & M-WSOC & L-WSOC \\
\hline \multirow[t]{6}{*}{$\begin{array}{l}\text { Dicarboxylic } \\
\text { Acid }\end{array}$} & Oxalic acid, $\mathrm{C}_{2}$ & 90 & 12 & $50,260,430$ & 100 & $\bigcirc$ & \\
\hline & Succinic acid, $\mathrm{C}_{4}$ & 118 & 8.8 & 380 & 100 & $\bigcirc$ & \\
\hline & Maleic acid, $\mathrm{C}_{4}$ & 116 & 80.4 & 405 & 100 & $\bigcirc$ & \\
\hline & Fumaric acid, $\mathrm{C}_{4}$ & 116 & 0.63 & 470 & 0 & & $\bigcirc$ \\
\hline & Adipic acid, $\mathrm{C}_{6}$ & 146 & 2.5 & 120 & 0 & & $\bigcirc$ \\
\hline & Azelaic acid, $\mathrm{C}_{9}$ & 188 & 0.21 & 280 & 0 & & $\bigcirc$ \\
\hline \multirow[t]{2}{*}{ Carbonyls } & Glyoxal & 58 & $\geq 67$ & 120 & 100 & $\bigcirc$ & \\
\hline & Methyl glyoxal & 72 & $\geq 67$ & 90 & 100 & $\bigcirc$ & \\
\hline Amines & Ethanolamine & 61 & Infinity $^{c}$ & 160 & 100 & 0 & \\
\hline \multirow[t]{2}{*}{ Saccharides } & Levoglucosan & 162 & $\mathrm{~N} / \mathrm{A}^{\mathrm{d}}$ & 330 & 100 & 0 & \\
\hline & Sucrose & 342 & 211.5 & 80,290 & 100 & $\bigcirc$ & \\
\hline Phenols & Catechol & 110 & 43 & 220 & 0 & & $\bigcirc$ \\
\hline Aromatic acids & Phthalic acid & 166 & 0.7 & 200 & 0 & & 0 \\
\hline \multirow[t]{2}{*}{ Cyclic acids } & Pinic acid & 186 & $\mathrm{~N} / \mathrm{A}^{\mathrm{d}}$ & 110 & 0 & & 0 \\
\hline & cis-Pinonic acid & 184 & $\mathrm{~N} / \mathrm{A}^{\mathrm{d}}$ & 320 & 0 & & $\bigcirc$ \\
\hline Humic-like & $\begin{array}{l}\text { Suwannee River } \\
\text { fulvic }\end{array}$ & --- & $\mathrm{N} / \mathrm{A}^{\mathrm{c}}$ & $70,250,520$ & 0 & & $\bigcirc$ \\
\hline
\end{tabular}

a 'MW' denotes molecular weight.

${ }^{\mathrm{b}}$ The values are those summarized in Saxena and Hildemann [1996].

c 'Infinity' denotes complete miscibility with water.

d 'N/A' denotes that solubility data is not readily available. 
Table 2. Summary of the average concentrations of OC, WSOC, diacids, ketoacids, and $\alpha$-dicarbonyls in the aerosol samples collected in New Delhi, India ${ }^{a}$

\begin{tabular}{|c|c|c|c|}
\hline & \multirow{2}{*}{$\begin{array}{l}\text { Groups/Compounds/ } \\
\text { Abbreviations }\end{array}$} & \multicolumn{2}{|c|}{ Concentrations } \\
\hline & & Daytime & Nighttime \\
\hline \multicolumn{2}{|l|}{$\begin{array}{l}\mathrm{OC} \\
\left(\mu \mathrm{gC} \mathrm{m}{ }^{-3}\right)\end{array}$} & $60.1(16.0-110.4)$ & $76.7(31.8-159.5)$ \\
\hline \multirow{3}{*}{$\begin{array}{l}\text { TWSOC } \\
\left(\mu g C \mathrm{~m}^{-3}\right)\end{array}$} & M-WSOC & $9.4(3.5-14.7)$ & $6.1(1.6-10.2)$ \\
\hline & L-WSOC & $11.4(5.3-16.8)$ & $13.1(6.5-45.2)$ \\
\hline & Total & $20.8(8.8-31.5)$ & $19.2(8.4-53.8)$ \\
\hline \multirow{20}{*}{$\begin{array}{l}\text { Diacids } \\
\left(\mathrm{ng} \mathrm{m}^{-3}\right)\end{array}$} & Oxalic acid, $\mathrm{C}_{2}$ & 955 (396-1619) & $1906(517-4531)$ \\
\hline & Malonic, $\mathrm{C}_{3}$ & $181(85-254)$ & 194(101-242) \\
\hline & Succinic acid, $\mathrm{C}_{4}$ & $273(150-636)$ & $330(165-605)$ \\
\hline & Maleic acid, M & $18(6-77)$ & $36(6-182)$ \\
\hline & Fumaric acid, F & $9(3-46)$ & $10(3-19)$ \\
\hline & Glutaric, $\mathrm{C}_{5}$ & $51(28-122)$ & $66(25-144)$ \\
\hline & Adipic acid, $\mathrm{C}_{6}$ & $29(17-69)$ & $32(14-46)$ \\
\hline & Pimelic, $\mathrm{C}_{7}$ & $15(6-37)$ & $16(5-28)$ \\
\hline & Suberic, $\mathrm{C}_{8}$ & $5(1-11)$ & $5(1-11)$ \\
\hline & Azelaic acid, $\mathrm{C}_{9}$ & $70(26-168)$ & $72(44-115)$ \\
\hline & Sebacic, $\mathrm{C}_{10}$ & $8(3-23)$ & $10(4-15)$ \\
\hline & Methylmalonic, $\mathrm{iC}_{4}$ & $9(4-12)$ & $12(6-23)$ \\
\hline & Methylsuccinic, $\mathrm{iC}_{5}$ & $39(9-102)$ & $53(17-95)$ \\
\hline & Methylglutaric, $\mathrm{iC}_{6}$ & $7(3-21)$ & $8.5(3-13)$ \\
\hline & Methylmaleic, mM & $21(4-82)$ & $24(8-38)$ \\
\hline & Phthalic, $\mathrm{Ph}$ & $40(22-95)$ & $45(14-76)$ \\
\hline & Iso-phthalic, iPh & $8(3-19)$ & $11(4-24)$ \\
\hline & Tere-phthalic, tPh & $5(3-9)$ & $4(1-11)$ \\
\hline & Malic, $\mathrm{hC}_{4}$ & $9(3-30)$ & $9(4-17)$ \\
\hline & Sub total & $1777(835-2835)$ & 2875 (979-6030) \\
\hline \multirow{6}{*}{$\begin{array}{l}\text { Ketoacids } \\
\left(\operatorname{ng~m}^{-3}\right)\end{array}$} & Pyruvic, Pyr & $18(1-80)$ & $9(1-32)$ \\
\hline & Glyoxylic, $\omega \mathrm{C}_{2}$ & $114(27-508)$ & $128(19-245)$ \\
\hline & 3-Oxopropanoic, $\omega \mathrm{C}_{3}$ & $5(3-15)$ & $6(2-17)$ \\
\hline & 4-Oxobutanoic, $\omega \mathrm{C}_{4}$ & $19(11-35)$ & $15(9-23)$ \\
\hline & 9-Oxononanoic, $\omega \mathrm{C}_{9}$ & $1(0.4-4)$ & $2(0.4-7)$ \\
\hline & Sub total & $157(42-642)$ & $161(31-324)$ \\
\hline \multirow{3}{*}{$\begin{array}{l}\alpha \text {-Dicarbonyls } \\
\left(\mathrm{ng} \mathrm{m}^{-3}\right)\end{array}$} & Glyoxal, Gly & $12(1-41)$ & $24(4-72)$ \\
\hline & Methylglyoxal, mGly & $28(7-68)$ & $31(9-178)$ \\
\hline & Sub total & $40(8-109)$ & $55(13-250)$ \\
\hline
\end{tabular}

${ }^{a}$ Numbers in parenthesis in the concentration rows are ranges of the concentrations. 
Figure 1
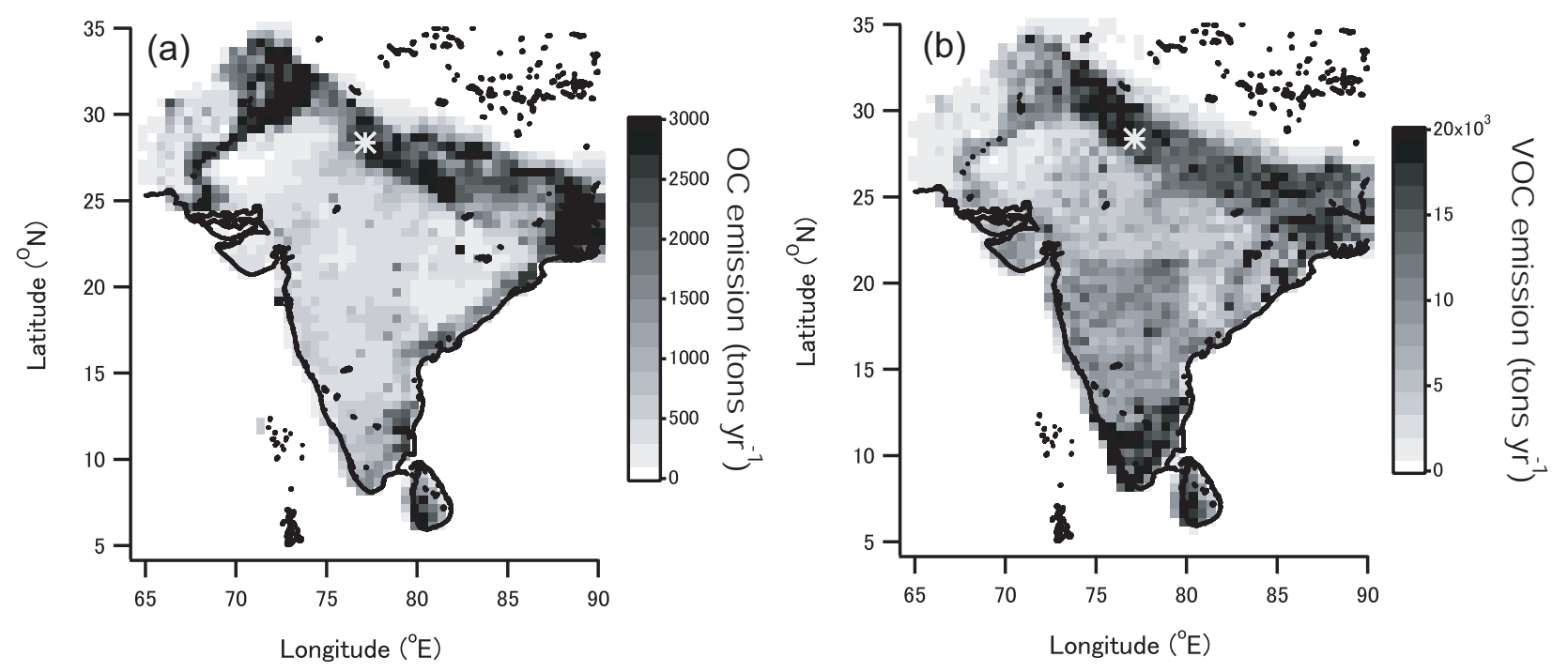
Figure 2

(a)

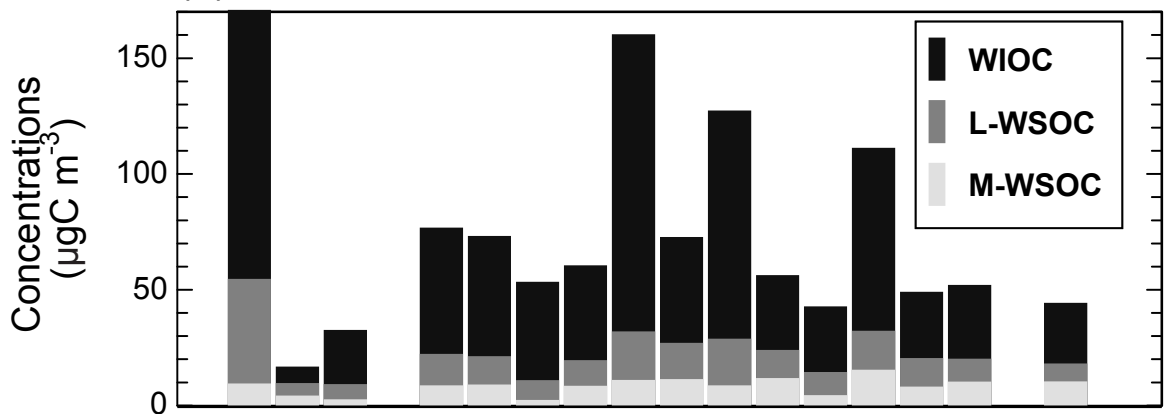

(b)

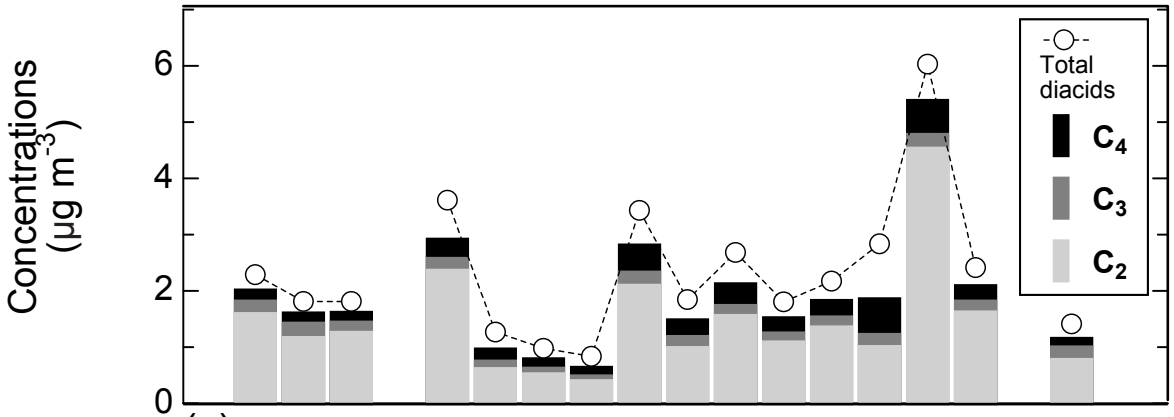

(c)
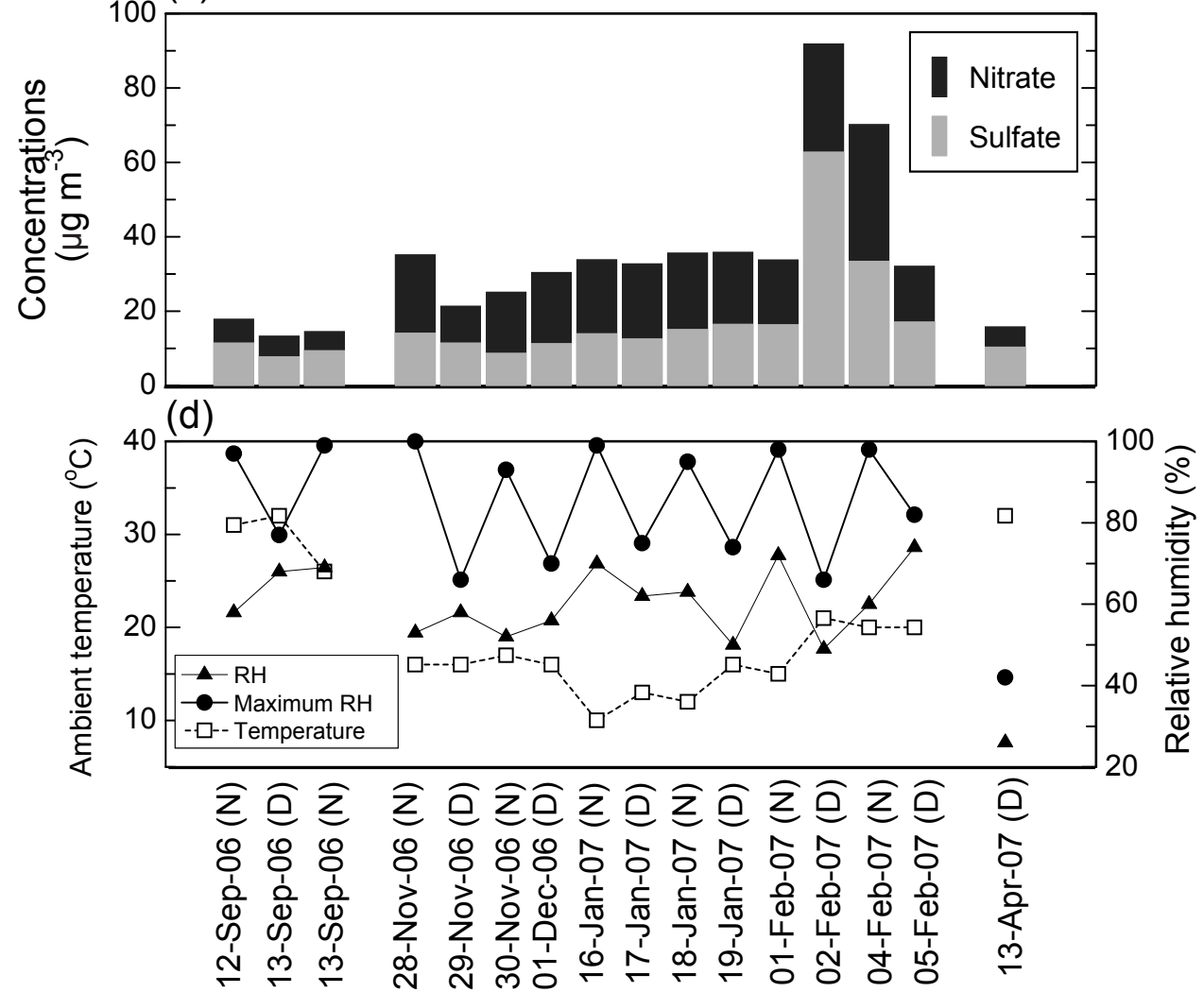
Figure 3

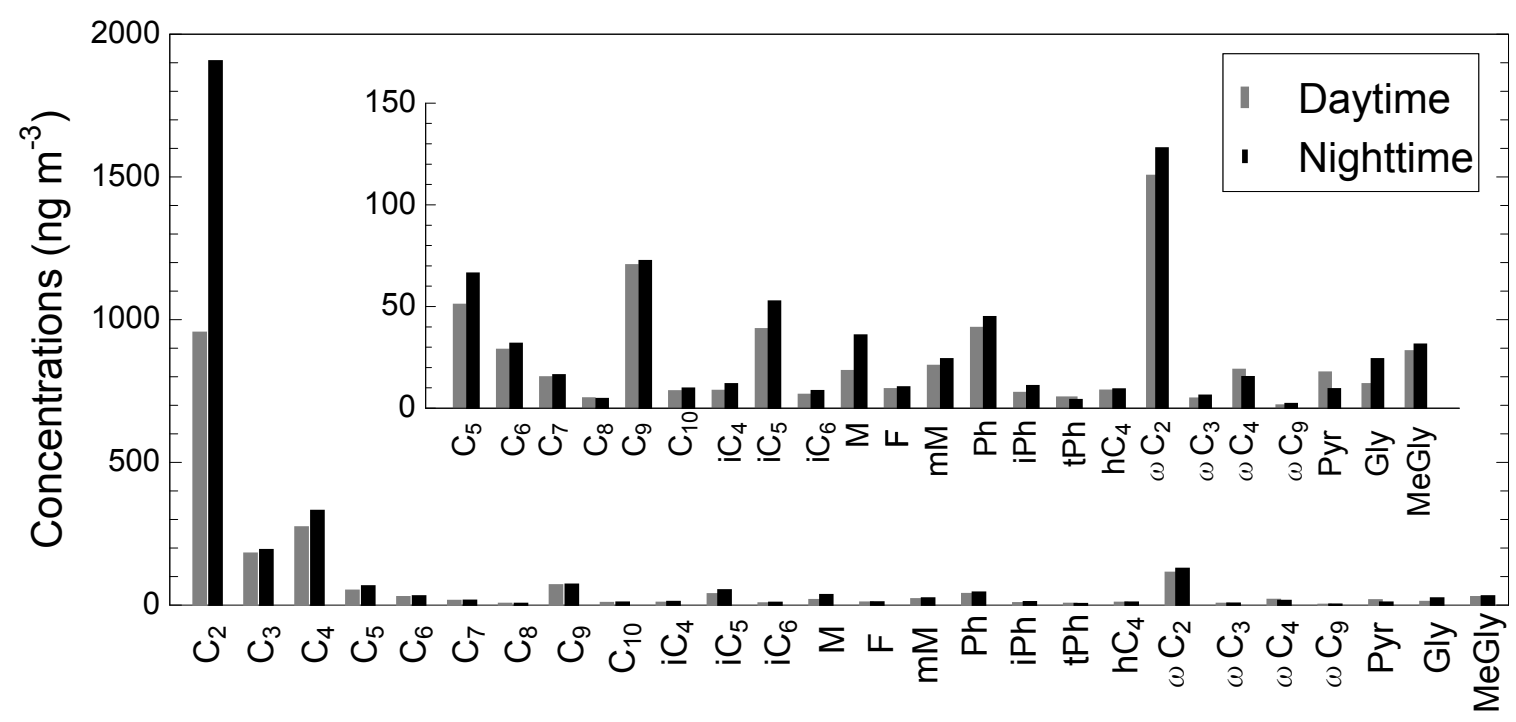


Figure 4
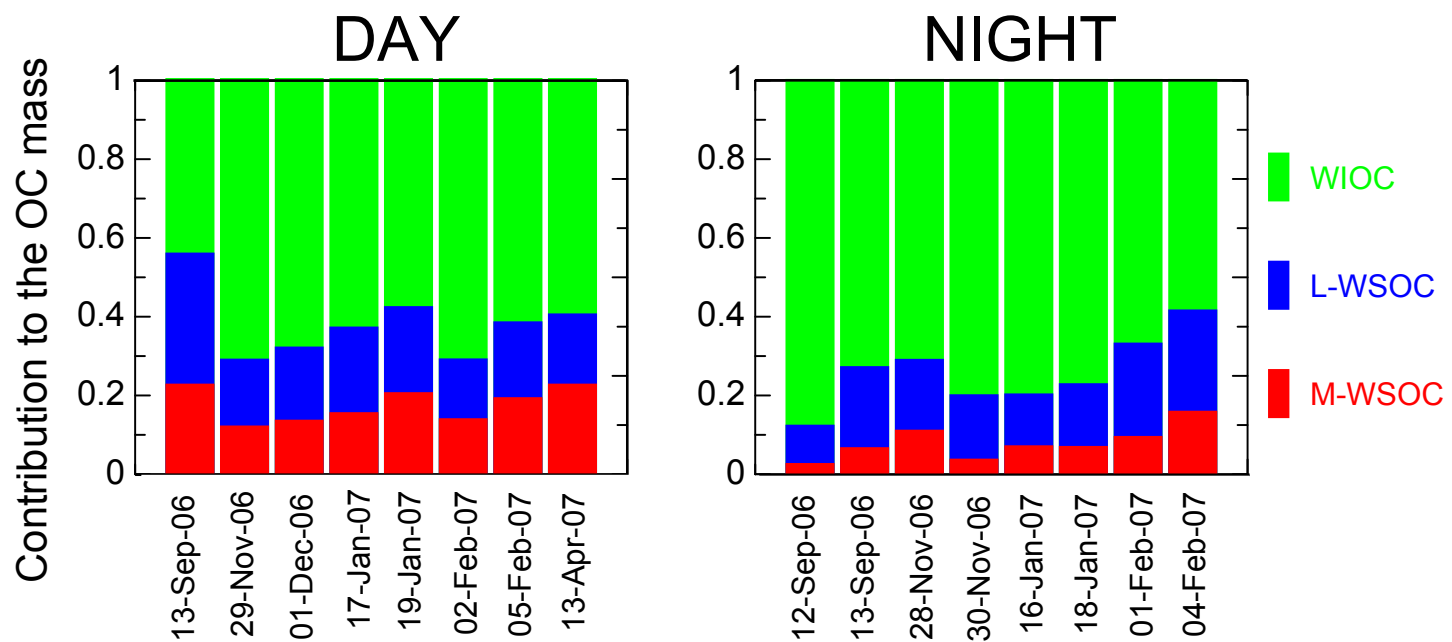
Figure 5
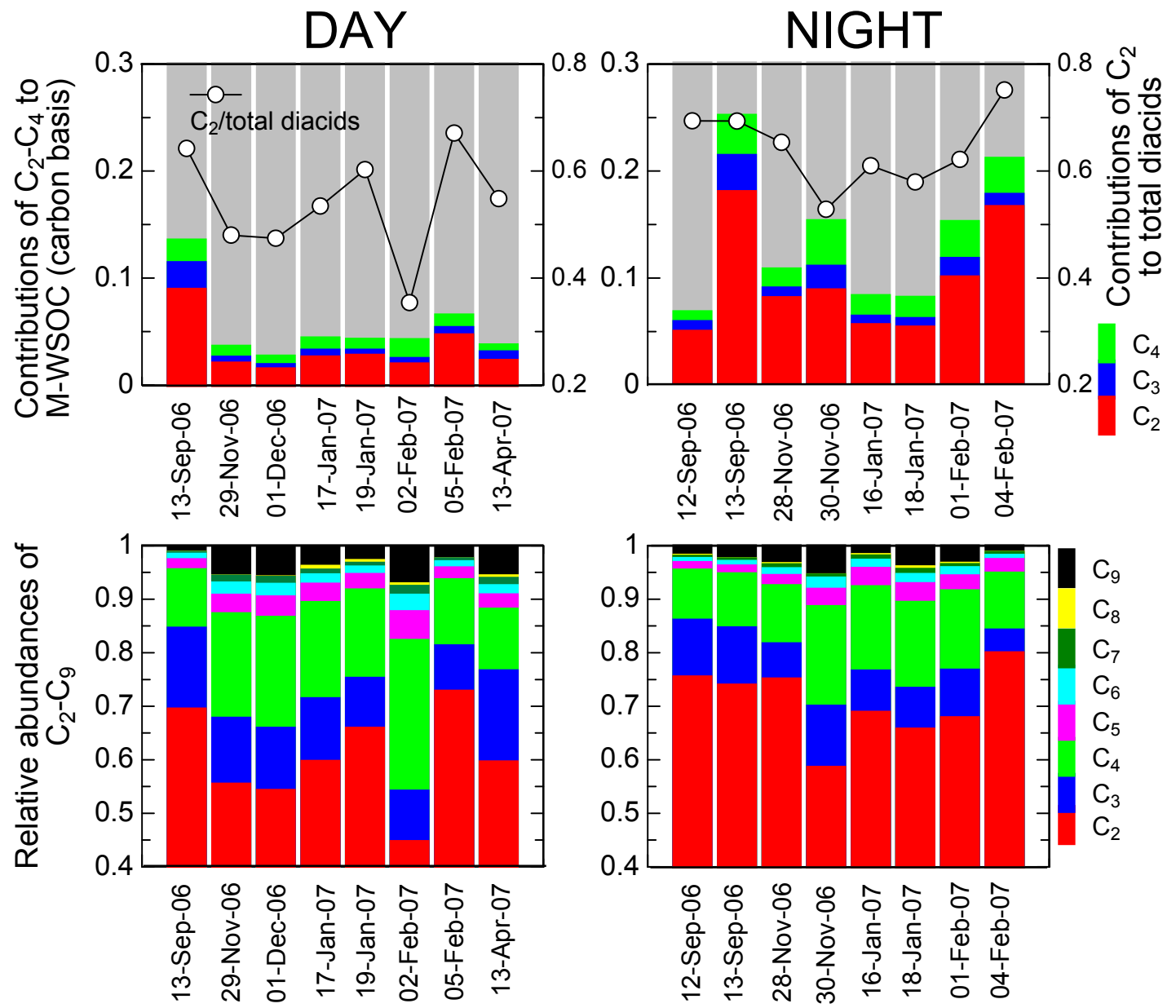
Figure 6

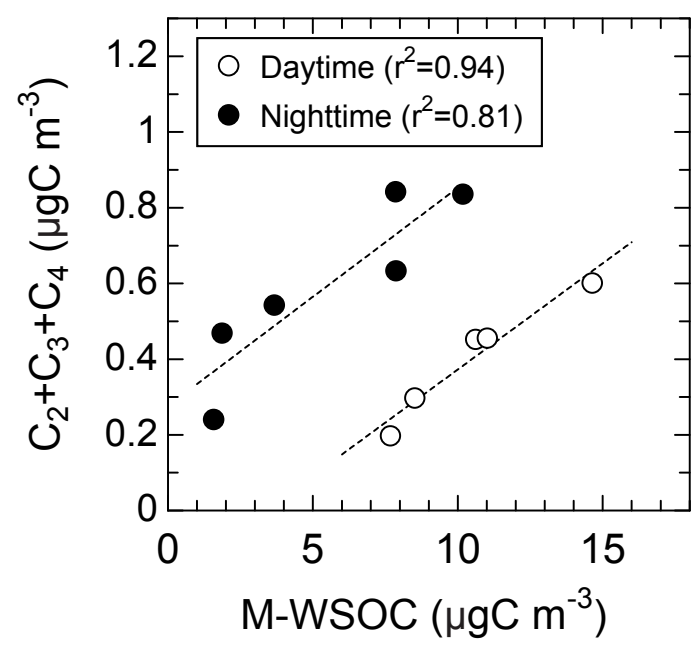


Figure 7
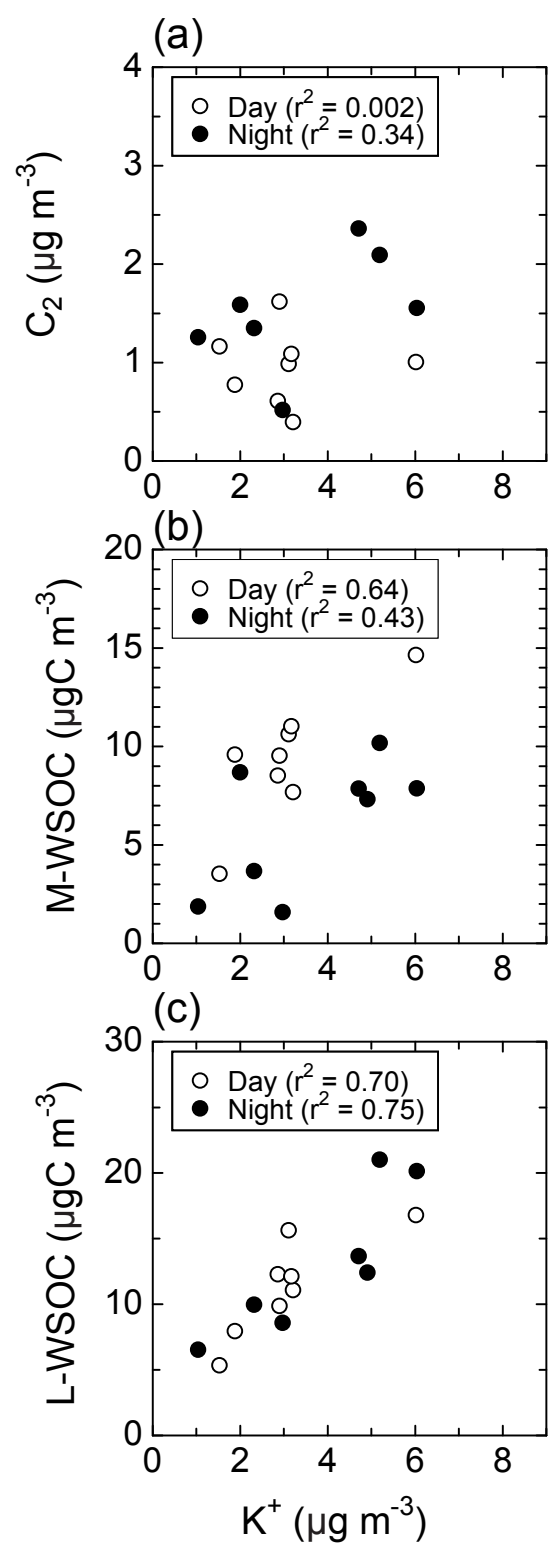
Figure 8

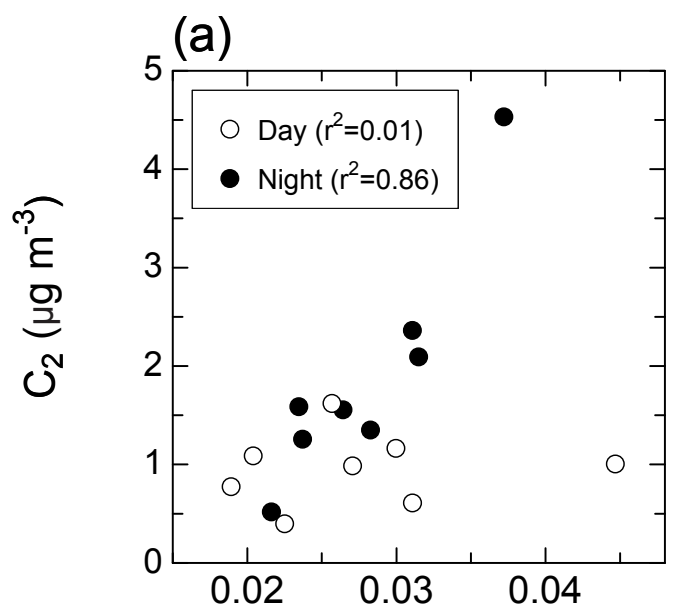

(b)

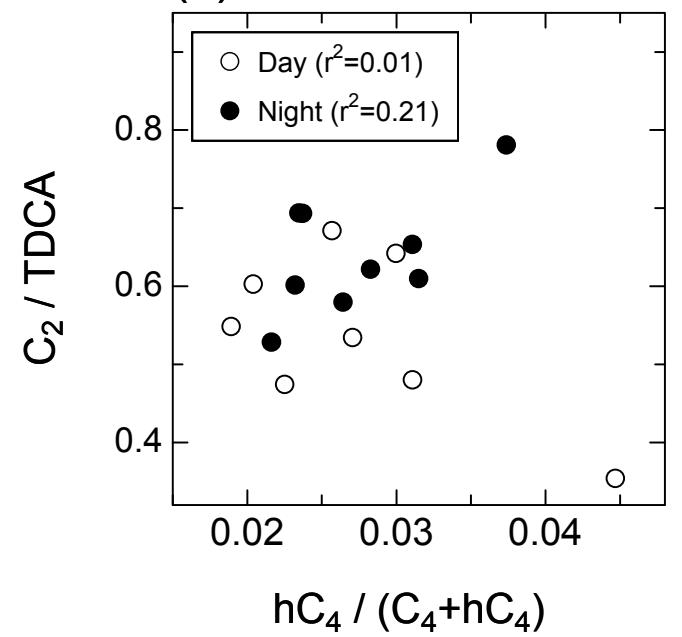


Figure 9

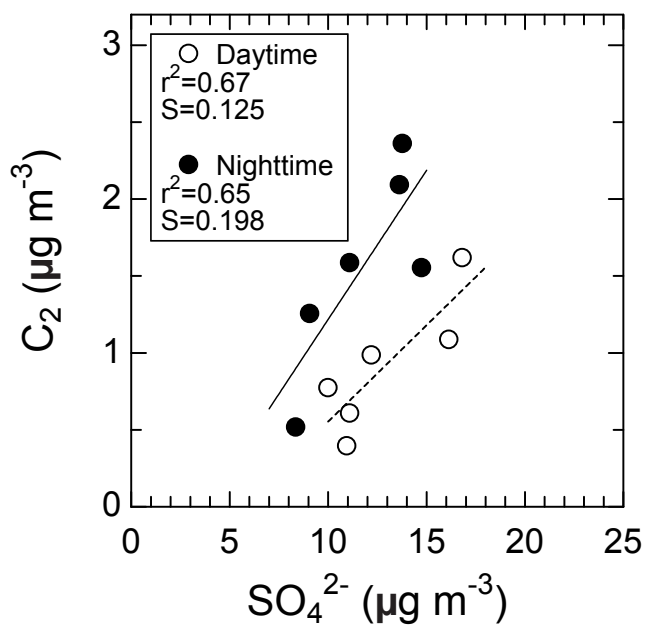

